\title{
Bridging the Faraoni and Selli oceanic anoxic events: late Hauterivian to early Aptian dysaerobic to anaerobic phases in the Tethys
}

\author{
K. B. Föllmi ${ }^{1}$, M. Bôle, ${ }^{2,}$, N. Jammet ${ }^{2}$, P. Froidevaux ${ }^{2, * *}$, A. Godet ${ }^{1}$, S. Bodin ${ }^{3}$, T. Adatte ${ }^{1}$, V. Matera ${ }^{2,4}$, D. Fleitmann ${ }^{5}$, \\ and J. E. Spangenberg ${ }^{6}$ \\ ${ }^{1}$ Institut de Géologie et Paléontologie, Université de Lausanne, Lausanne, Switzerland \\ ${ }^{2}$ Institut de Géologie et Hydrogéologie, Université de Neuchâtel, Neuchâtel, Switzerland \\ ${ }^{3}$ Institut für Geologie, Mineralogie und Geophysik, Ruhr-Universität, Bochum, Germany \\ ${ }^{4}$ Institut National de Recherche et de Sécurité, Vandoeuvre-Les-Nancy, France \\ ${ }^{5}$ Institute of Geological Sciences, University of Bern, Bern, Switzerland \\ ${ }^{6}$ Institut de Minéralogie et Géochimie, Université de Lausanne, Lausanne, Switzerland \\ * present address: Departement für Erdwissenschaften, ETH, Zürich, Switzerland \\ *** present address: Institut für Atmosphäre und Klima, ETH Zürich, Switzerland
}

Correspondence to: K. B. Föllmi (karl.foellmi@unil.ch)

Received: 7 June 2011 - Published in Clim. Past Discuss.: 22 June 2011

Revised: 7 December 2011 - Accepted: 17 December 2011 - Published: 30 January 2012

\begin{abstract}
A detailed geochemical analysis was performed on the upper part of the Maiolica Formation in the Breggia (southern Switzerland) and Capriolo sections (northern Italy). The analysed sediments consist of well-bedded, partly siliceous, pelagic carbonate, which lodges numerous thin, dark and organic-rich layers. Stable-isotope, phosphorus, organic-carbon and a suite of redox-sensitive trace-element contents (RSTE: Mo, U, Co, V and As) were measured. The RSTE pattern and $\mathrm{C}_{\text {org }}: \mathrm{P}_{\text {tot }}$ ratios indicate that most organic-rich layers were deposited under dysaerobic rather than anaerobic conditions and that latter conditions were likely restricted to short intervals in the latest Hauterivian, the early Barremian and the pre-Selli early Aptian.
\end{abstract}

Correlations are both possible with organic-rich intervals in central Italy (the Gorgo a Cerbara section) and the Boreal Lower Saxony Basin, as well as with the facies and drowning pattern in the Helvetic segment of the northern Tethyan carbonate platform. Our data and correlations suggest that the latest Hauterivian witnessed the progressive installation of dysaerobic conditions in the Tethys, which went along with the onset in sediment condensation, phosphogenesis and platform drowning on the northern Tethyan margin, and which culminated in the Faraoni anoxic episode.
This episode is followed by further episodes of dysaerobic conditions in the Tethys and the Lower Saxony Basin, which became more frequent and progressively stronger in the late early Barremian. Platform drowning persisted and did not halt before the latest early Barremian. The late Barremian witnessed diminishing frequencies and intensities in dysaerobic conditions, which went along with the progressive installation of the Urgonian carbonate platform. Near the Barremian-Aptian boundary, the increasing density in dysaerobic episodes in the Tethyan and Lower Saxony Basins is paralleled by a change towards heterozoan carbonate production on the northern Tethyan shelf. The following return to more oxygenated conditions is correlated with the second phase of Urgonian platform growth and the period immediately preceding and corresponding to the Selli anoxic episode is characterised by renewed platform drowning and the change to heterozoan carbonate production. Changes towards more humid climate conditions were the likely cause for the repetitive installation of dys- to anaerobic conditions in the Tethyan and Boreal basins and the accompanying changes in the evolution of the carbonate platform towards heterozoan carbonate-producing ecosystems and platform drowning. 


\section{Introduction}

The Early and early Late Cretaceous represents a time interval of considerable paleoenvironmental change, which found its expression in the repeated installation of widespread dysto anaerobic conditions in outer-shelf and basinal settings (Schlanger and Jenkyns, 1976; Jenkyns, 1980; Weissert and Erba, 2004). One of the oldest "oceanic anoxic episodes" (OAE) of the Cretaceous dates from the latest Hauterivian and is known as the "Faraoni event" (Cecca et al., 1994). This episode was originally identified in the central Italian Apennines, where it is preserved in the form of a welldistinguishable interval of thin and closely spaced organicrich mudstone layers in pelagic carbonate (Cecca et al., 1994; Coccioni et al., 1998, 2006; Baudin et al., 2002; Baudin, 2005). A coeval equivalent of the Faraoni Level was subsequently found in northeastern Italy (eastern part of the Trento Plateau and Lessini Mountains; Cecca et al., 1996; Faraoni et al., 1997; Baudin et al., 1997; Cismon, Venetian Alps; Erba et al., 1999; Tremolada et al., 2009) and in the southern Swiss Alps (Breggia; Bersezio et al., 2002). In the following, other Faraoni equivalents were identified outside the central Tethyan realm, such as in the Vocontian Basin (Vergons; Baudin et al., 1999), Ultrahelvetic Basin (Veveyse de Châtel St. Denis; Busnardo et al., 2003), and in the Rio Argos section of the Subbetic unit in Spain (Company et al., 2005). Further possible expressions of the Faraoni anoxic episode have been observed in northwestern Sicily (Bellanca et al., 2002; Baudin, 2005; Coccioni et al., 2006), offshore Portugal and Morocco (DSDP Sites 370 and 398; Baudin, 2005), the North Sea area (Mutterlose and Ruffell, 1999), and in the central and northwestern Pacific (Resolution Guyot, ODP Sites 865 and 866; Baudin et al., 1995; Izu-Mariana margin, ODP Site 1149; Shipboard Scientific Party, 2000; Bodin et al., 2007). Evidence for the presence of a Faraoni equivalent was also not excluded for the Argentinean Neuquén Basin (Tyson et al., 2005).

The early Aptian oceanic anoxic "Selli event" (Coccioni et al., 1987) was first seen as part of the broadly defined, Aptian-Albian OAE (Schlanger and Jenkyns, 1976), and was in the following labelled as OAE 1a (Arthur et al., 1990). OAE 1a is generally characterised by a large, positive excursion in $\delta^{13} \mathrm{C}$ values associated with enhanced organic matter burial (Weissert, 1981a). Organic-rich sediments associated with the OAE 1a have been documented from different marine basins, such as the Vocontian Basin (Bréhéret, 1988), the Lower Saxony Basin (Kemper and Zimmerle, 1978; Mutterlose et al., 2009), the southern Tethyan realm (Heldt et al., 2008), the central and southern Atlantic (Bralower et al., 1994) and the central and northwestern Pacific (Sliter, 1989; Bralower et al., 2002). Together with the Late Cenomanian "Bonarelli event", the Selli episode represents a model OAE for a wide range of investigations (e.g., Menegatti et al., 1998; Erba et al., 2010; Tejada et al., 2010; Stein et al., 2011). Both the Faraoni and Selli events have been associated with phases of intensified volcanic activity and associated environmental change, which led to higher nutrient availability, higher primary productivity rates and the corresponding development of oceanic anoxic conditions (e.g., Baudin, 2005; Tejada et al., 2009).

In the central Tethys and northern Atlantic, the pelagic sediments between the Faraoni and Selli OAEs are characterised by the presence of a series of thin, organic-rich mudstone layers, which have been interpreted as the result of short-lasting and cyclically reappearing anoxic episodes (Weissert et al., 1979, 1985; Weissert, 1981a; cf. also Herbert, 1992; Bralower et al., 1994; Bersezio et al., 2002). Intermittent anoxic conditions spanning the latest Hauterivian to the early Aptian time interval have also been documented from the Lower Saxony Basin (Mutterlose et al., 2009, 2010). Brief anoxic episodes predating the Selli event have equally been established from the southern Atlantic and MidPacific (e.g., Bralower et al., 1994). These short-lived anoxic episodes bridging the Faraoni and Selli OAEs are generally less well characterised in terms of their geochemistry, and their implications for the general paleoceanographic and paleoenvironmental conditions during this time interval are less well established. It is for example not known, if these short episodes have their expression in shallow-water sediments, and if they had a larger-scale, inter-basinal impact.

In this contribution, we present new insights on the time interval spanning the late Hauterivian and earliest Aptian based on data from the Breggia and Capriolo sections in southern Switzerland and northern Italy, respectively (Fig. 1). These two sections are complementary with regards to their age ranges and offer the possibility to cover the time interval between the late Hauterivian and earliest Aptian. Based both on our data and their interpretation, as well as a comparison with the literature, we suggest that (1) these short-lasting anoxic events were widespread within the central Tethys, (2) can be correlated with their counterparts in the boreal Lower Saxony Basin, (3) are correlated with changes in the ecology of carbonate-producing benthos on adjacent shallow-water carbonate platforms, and (4) may have resulted from brief phases of warmer and more humid climate conditions.

\section{The Breggia and Capriolo sections}

The Breggia section is located in southern Switzerland, in an abandoned quarry near the Breggia Gorge, close to Balerna (canton Ticino; Fig. 1). The Capriolo section has been measured in the upper part of an abandoned quarry northeast of Capriolo, southwest of the Lago d'Iseo, in northern Italy (Fig. 1). In both sections, the upper part of the Maiolica Formation has been sampled, which consists of a light-coloured, pelagic, micritic carbonate including siliceous levels and nodules, and thin and dark-coloured mudstone interlayers. 


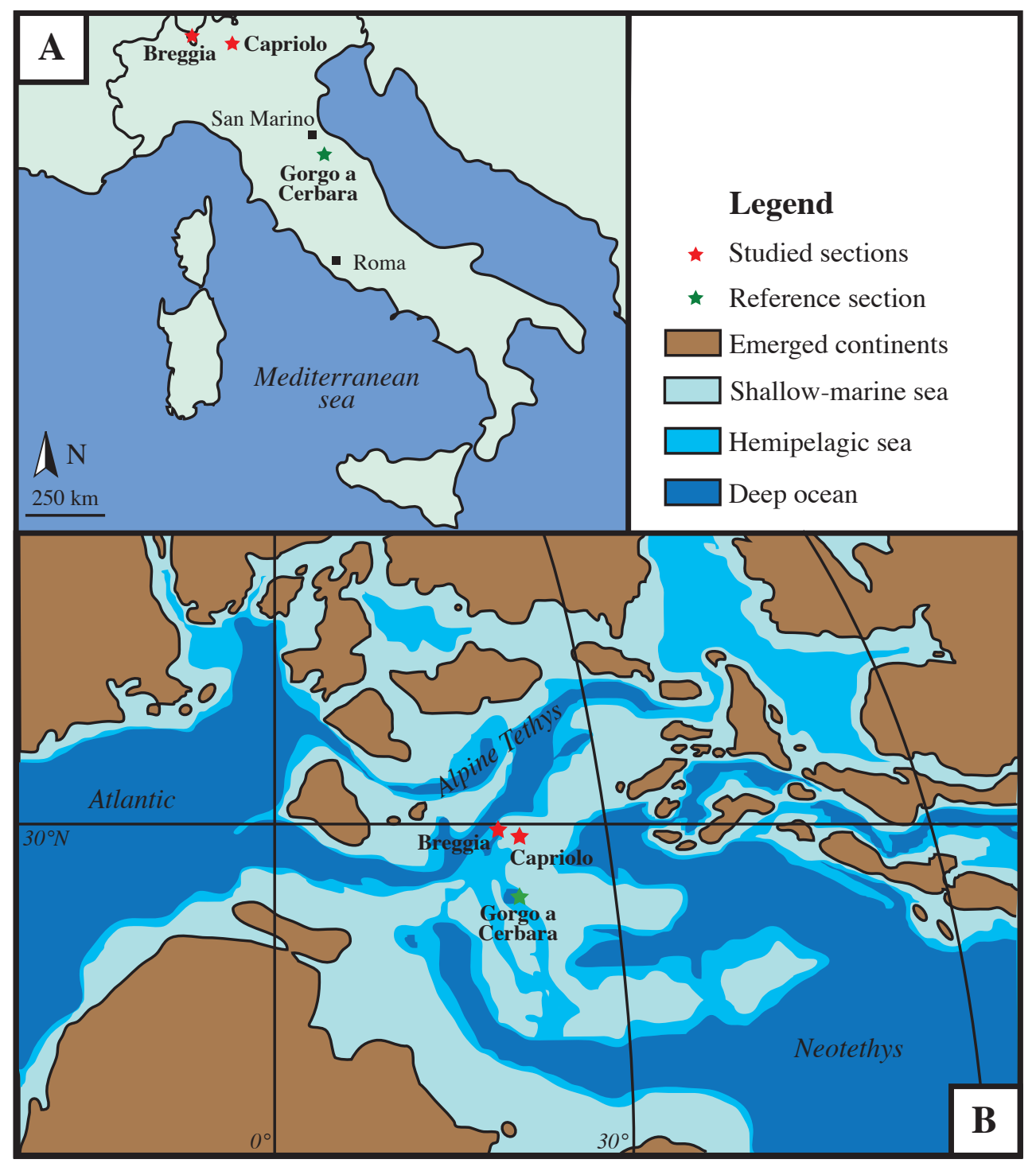

Fig. 1. Location of the studied sections and a reference section on a geographic map (A) and on a paleogeographic reconstruction for the early Aptian from Blakey (http://cpgeosystems.com/paleomaps.html) (B). Modified from Stein et al. (2011).

For both sections, the magnetostraphies by Channel et al. (1987, 1993, 1995, 2000) and Channel and Erba (1992) were projected onto the measured sections. In addition, a crosscheck was performed by the analysis of calcareous nannofossils on selected mudstone samples. We used the last appearance of Lithraphidites bollii as a fix point to correct for apparent differences in measured thicknesses between the published and our sections. The second fix point used in both sections consists of the top of the Maiolica Formation. The resulting stratigraphies indicate that for the Breggia section, the upper Hauterivian and lower Barremian intervals are quite complete and that the top of the Maiolica Formation is marked by a major hiatus, which starts in the early late Barremian. The overlying Scaglia variegata is already of Aptian age.
The Maiolica Formation in the Capriolo section extends well into the lower Aptian. Unfortunately, its Barremian interval is incomplete and cannot be confidently subdivided by magnetostratigraphy, as was already stated by Channell and Erba (1992). Based on the first appearance of Rucinolithus irregularis (Channell and Erba, 1992) we assume that the normal magnetochron underneath $\mathrm{CMO}$ represents at least in part CM1. As such, most of the upper Barremian interval may have been preserved, whereas the lower Barremian interval appears largely reduced. Also the uppermost Hauterivian succession shows slumped intervals. The lowermost Aptian interval appears, on the contrary, well preserved.

Besides for its magnetostratigraphy and nannofossil biostratigraphy, the Hauterivian to Barremian interval in the Breggia section was also investigated for its facies and 
sedimentology by Weissert $(1979,1981 \mathrm{~b})$ and Weissert et al. (1979); stable carbon-isotope composition by Weissert et al. (1985); clay-mineral composition by Deconinck and Bernoulli (1991); organic matter by Arthur and PremoliSilva (1982) and Bersezio et al. (2002); ammonites by Rieber (1977); and aptychi by Renz and Habicht (1985). The Hauterivian to lowermost Aptian interval in the Capriolo section was furthermore described by Weissert (1981b).

Here we provide detailed stratigraphic logs and records of stable carbon and oxygen isotopes, organic-matter and phosphorus contents, and redox-sensitive trace element distributions for both sections. Our logging and sampling strategy consisted especially in the documentation and characterisation of the organic-rich layers present in both sections. This implies that longer intervening carbonate intervals were not sampled in high resolution.

\section{Methods}

\subsection{Organic-carbon analysis}

The total organic carbon (TOC) content of preserved organic matter was analysed on a Rock Eval ${ }^{\mathrm{TM}} 6$ (Espitalié et al., 1985), with an instrumental precision of $<2 \%$. Approximately $70 \mathrm{mg}$ of powdered sample was first pyrolyzed and subsequently completely oxidized. The amount of hydrocarbon released during pyrolysis was measured by a FID detector, whereas the amount of $\mathrm{CO}_{2}$ and $\mathrm{CO}$ during both steps was measured by infrared absorbance. A standard cycle was applied, in which pyrolysis started isothermally at $300^{\circ} \mathrm{C}$ for three minutes (S1: hydrocarbons released during the isothermal phase). The sample was then heated to $650^{\circ}$ (S2: hydrocarbons released between 300 and $650^{\circ} \mathrm{C}$ ). The oxidation step started isothermally at $400^{\circ}$ for three minutes ( $\mathrm{S} 3: \mathrm{CO}_{2}$ released) and subsequently, the sample was heated up to $850^{\circ}$. Obtained TOC contents are expressed in weight \% (wt \%). The hydrogen and oxygen indices $(\mathrm{HI}=\mathrm{S} 2 / \mathrm{TOC} \times 100$ in $\mathrm{mg}$ hydrocarbons per $\mathrm{g}$ TOC; OI $=\mathrm{S} 3 / \mathrm{TOC} \times 100$ in $\mathrm{mg} \mathrm{CO}_{2}$ per g TOC) were plotted in a Van Krevelen-type diagram and used to characterise preserved organic matter (Espitalié et al., 1985). Standard IFP 160000 was applied to calibrate the measurements. The error relative is $0.77,0.25$ and $1.5 \%$ for TOC, HI and OI, respectively.

\subsection{Total phosphorus analysis}

Total phosphorus (P) contents were measured on powdered bulk-rock samples. $1 \mathrm{ml}$ of $1 \mathrm{M} \mathrm{MgNO}_{3}$ was added to $100 \mathrm{mg}$ powder and the resulting solution was dried in an oven at $130^{\circ}$ during $30 \mathrm{~min}$. The sample was then heated at $550^{\circ}$ during two hours to oxidize the organic matter. After cooling, $10 \mathrm{ml}$ of $1 \mathrm{M} \mathrm{HCl}$ was added to the sample to liberate $\mathrm{P}$ and the solution was placed in a shaker during $16 \mathrm{~h}$. The solution was then filtered, diluted 10 times and mixed with
$100 \mu \mathrm{l}$ molybdate mixing reagent to form phosphomolybdic acid (Eaton et al., 1995). In the following, $100 \mu \mathrm{l}$ of ascorbic acid was added to reduce the acid and colour the solution blue. The intensity of the blue colour is a function of the $\mathrm{P}$ concentration. The total $\mathrm{P}$ content was measured by a UV/Vis spectrophotometer (Perking Elmer UV/Vis Spectrophotometer Lambda $10 ; \lambda=865 \mathrm{~nm})$. Selected samples were measured three times and the obtained precision is better than $5 \%$.

The $\mathrm{C}_{\text {org }}: \mathrm{P}_{\text {tot }}$ ratio was calculated in $\mathrm{mol} \mathrm{mol}^{-1}$ units for all measured samples.

\subsection{Stable carbon- and oxygen-isotope analysis}

Stable carbon- and oxygen-isotope ratios were measured on powdered bulk-rock samples using a Thermo Fisher Delta V Advantage at the University of Berne, and a Thermo Fisher Delta Plus XL at the University of Lausanne, both equipped with an automated carbonate preparation line. The results were calibrated to the Vienna Pee Dee Belemnite (V-PDB) scale with a standard deviation better than $0.05 \%$ for $\delta^{13} \mathrm{C}$ and $1 \%$ for $\delta^{18} \mathrm{O}$.

\subsection{Redox-sensitive trace-element analysis}

Carbonate samples were analysed for molybdenum (Mo), uranium $(\mathrm{U})$, cobalt $(\mathrm{Co})$, vanadium $(\mathrm{V})$, and arsenic (As) contents. These elements are considered as redox-sensitive trace elements (RSTE), which are used as an indicator of the presence and intensity of oxygen depletion at the site of sediment deposition (Algeo and Maynard, 2004; Tribovillard et al., 2006; Bodin et al., 2007).

$10 \mathrm{ml}$ suprapur nitric acid $\left(\mathrm{HNO}_{3}\right)$ was added to $250 \mathrm{mg}$ of rock sample reduced to powder in a PFA vessel and subsequently digested in a microwave oven (MSL-Ethos plus, Milestone; heating program EPA 3051). The solution was cooled, filtered $(0.45 \mu \mathrm{m})$ and diluted to $100 \mathrm{ml}$ with ultrapure water (Bodin et al., 2007). Dissolution percentages determined after filtration were between 89 and $94 \mathrm{wt} \%$ for all carbonate samples. Westermann et al. (2010) showed for comparable pelagic carbonates of Valanginian age from the same Breggia and Capriolo sections that RSTE contents and dissolution percentages are not positively correlated. This suggests that the RSTE are present in the soluble carbonate phase and not derived from partial leaching of the detrital fraction (cf. also Bodin et al., 2007). The RSTE data were, therefore, not normalized by aluminum contents.

RSTE contents (in ppm) were determined by a quadrupole ICP-MS (ELAN 6100, Perkin Elmer) in a semi-quantitative mode (totalQuant ${ }^{\mathrm{TM}}$ ), with a precision of $5 \%$. The calibration was based on two certified reference materials (LKSD-1 lake sediment and NIST-1640 natural water). 


\section{Results}

\subsection{Total organic carbon}

Samples of the dark, laminated and organic-rich layers in the Breggia section show TOC values between 0.9 and $12.6 \mathrm{wt} \%$, whereas those of the Capriolo section vary between 0.2 and $14.7 \mathrm{wt} \%$ (Figs. 2 and 3). The TOC values in the Breggia section are generally higher (mean value $=3.7 \mathrm{wt} \%, n=24$ ) than those in the Capriolo section (mean value $=2 \mathrm{wt} \% ; n=25$ ). The highest TOC values in the Breggia section are registered in two layers below the Hauterivian-Barremian boundary. Generally, the Barremian mudstone layers in the Breggia section are somewhat richer than their upper Hauterivian counterparts. In the Capriolo section, all measured mudstone layers show relatively low TOC values, with the exception of one layer in the lower Aptian part of the section (Figs. 2 and 3).

$\mathrm{HI}$ and $\mathrm{OI}$ of the organic matter preserved in the mudstone layers of both sections range between approximately 90 $370 \mathrm{mg} \mathrm{HC} \mathrm{g}^{-1}$ TOC and $20-120 \mathrm{mg} \mathrm{CO}_{2} \mathrm{~g}^{-1}$ TOC (Breggia), and 30-300 $\mathrm{mg} \mathrm{HCg}^{-1} \mathrm{TOC}$ and $30-120 \mathrm{mg} \mathrm{CO}_{2} \mathrm{~g}^{-1}$ TOC (Capriolo). In a Van Krevelen-type diagram, the preserved organic matter plots mostly within or nearby the type III field (Fig. 4).

\subsection{Total phosphorus}

Total P contents were measured on a series of carbonate and mudstone samples. In samples of the Breggia section, total $\mathrm{P}$ contents for carbonates and mudstones vary between approximately 100 and $250 \mathrm{ppm}$, and 250 and $1000 \mathrm{ppm}$, respectively, whereas in the Capriolo section, total $\mathrm{P}$ contents range between approximately 70 and $280 \mathrm{ppm}$ in carbonate samples and 100 and $1000 \mathrm{ppm}$ in mudstone samples (Figs. 2 and 3). Sporadic outliers are noted in Figs. 2 and 3, but are not further considered.

The stratigraphic evolution in total $\mathrm{P}$ contents in carbonates of the Breggia section is marked by two maxima around $250 \mathrm{ppm}$ within the upper Hauterivian and a further maximum around $250 \mathrm{ppm}$ in the middle lower Barremian interval. In the Capriolo section, carbonate $\mathrm{P}$ contents are generally higher in the Barremian and lower Aptian interval, in comparison to the upper Hauterivian interval. In both sections, the mudstone samples display rather disparate spreads of values, and trends are difficult to be discerned.

In the Breggia section, the $\mathrm{C}_{\text {org }}: \mathrm{P}_{\text {tot }}$ molar ratios show departures above 300 in mudstone levels with higher TOC values ( $>4 \mathrm{wt} \%$; Fig. 2) dating from the latest Hauterivian and middle early Barremian. Similar departures are observed in two layers above the Hauterivian-Barremian boundary and one layer within the lower Aptian interval of the Capriolo section. There, the Barremian levels are not necessarily those with the highest TOC levels, whereas the lower Aptian level is the one, which possesses the highest TOC value of the entire measured section $(14.7 \mathrm{wt} \%)$.

\subsection{Stable carbon isotopes}

For the purpose of this contribution, only the carbon-isotope records will be discussed, since they serve as correlation tools. The $\delta^{13} \mathrm{C}$ record of the Breggia section shows comparable values and a consistent trend for both the carbonate and mudstone samples (Fig. 5). It is characterised by rather stable values for the upper Hauterivian interval at around $1.5 \%$. The $\delta^{13} \mathrm{C}$ record rises to maximal values around $1.8 \%$ in the Hauterivian-Barremian boundary interval. In the following, the $\delta^{13} \mathrm{C}$ values slowly decrease to near $1.5 \%$ and increase again to fluctuate around $1.8 \%$ for the remainder of the lower Barremian interval. Just above the boundary between the lower and upper Barremian, the $\delta^{13} \mathrm{C}$ record increases by approximately $1 \%$ o to values of $2.5 \%$.

The $\delta^{13} \mathrm{C}$ record of the Capriolo section is only shown for the carbonate samples (Fig. 6), since the mudstone samples show systematic negative offsets of up to $0.8 \%$ o relative to the carbonate samples, probably because of diagenetic overprint. The carbonate samples of the upper Hauterivian interval are characterised by a gentle trend towards more negative values from near $2 \%$ to $1.8 \%$, followed by a shortlasting positive trend to around $1.9 \%$ and a renewed negative trend towards a minimum of $1.5 \%$ near the HauterivianBarremian boundary. $\delta^{13} \mathrm{C}$ values in the lower part of the Barremian interval are rather stable and fluctuate between 1.5 and $1.8 \%$, whereas in the upper part, they move to a maximum of near $2.2 \%$. The Barremian-Aptian boundary interval shows a negative excursion to a minimal value of near $1.8 \%$, which is followed by an irregular positive trend towards values of $2.2 \%$ near the top of the section (Fig. 6).

\subsection{Redox-sensitive trace elements}

Selected carbonate samples in the Breggia section show Mo, U, Co, V and As contents between 0-471 ppb, 0-2655 ppb, 1105-11493 ppb, 1243-3763 ppb, and 0-4912 ppb, respectively (Fig. 7). Mean values for Mo, U, Co, V and As are 108 ppb, 500 ppb, 2976 ppb, 2252 ppb, and 936 ppb $(n=19)$. Departures of these mean values are seen for levels underneath the Hauterivian-Barremian boundary (for all measured RSTE) and in the upper Barremian interval (for $\mathrm{U}$ and $\mathrm{Co}$ ).

In carbonate samples of the Capriolo section, $\mathrm{Mo}, \mathrm{U}, \mathrm{Co}$, $\mathrm{V}$ and As contents range between 0-545 ppb, 43-3557 ppb, 964-8127 ppb, 1219-13941 ppb, and 0-2883 ppb, respectively (Fig. 8). The mean values for Mo, U, Co, V and As are $71 \mathrm{ppb}, 451 \mathrm{ppb}, 2051 \mathrm{ppb}, 2618 \mathrm{ppb}$, and $442 \mathrm{ppb}(n=42)$. Excursions in RSTE contents are observed for carbonates underneath the Hauterivian-Barremian boundary and within the lower Aptian interval. 


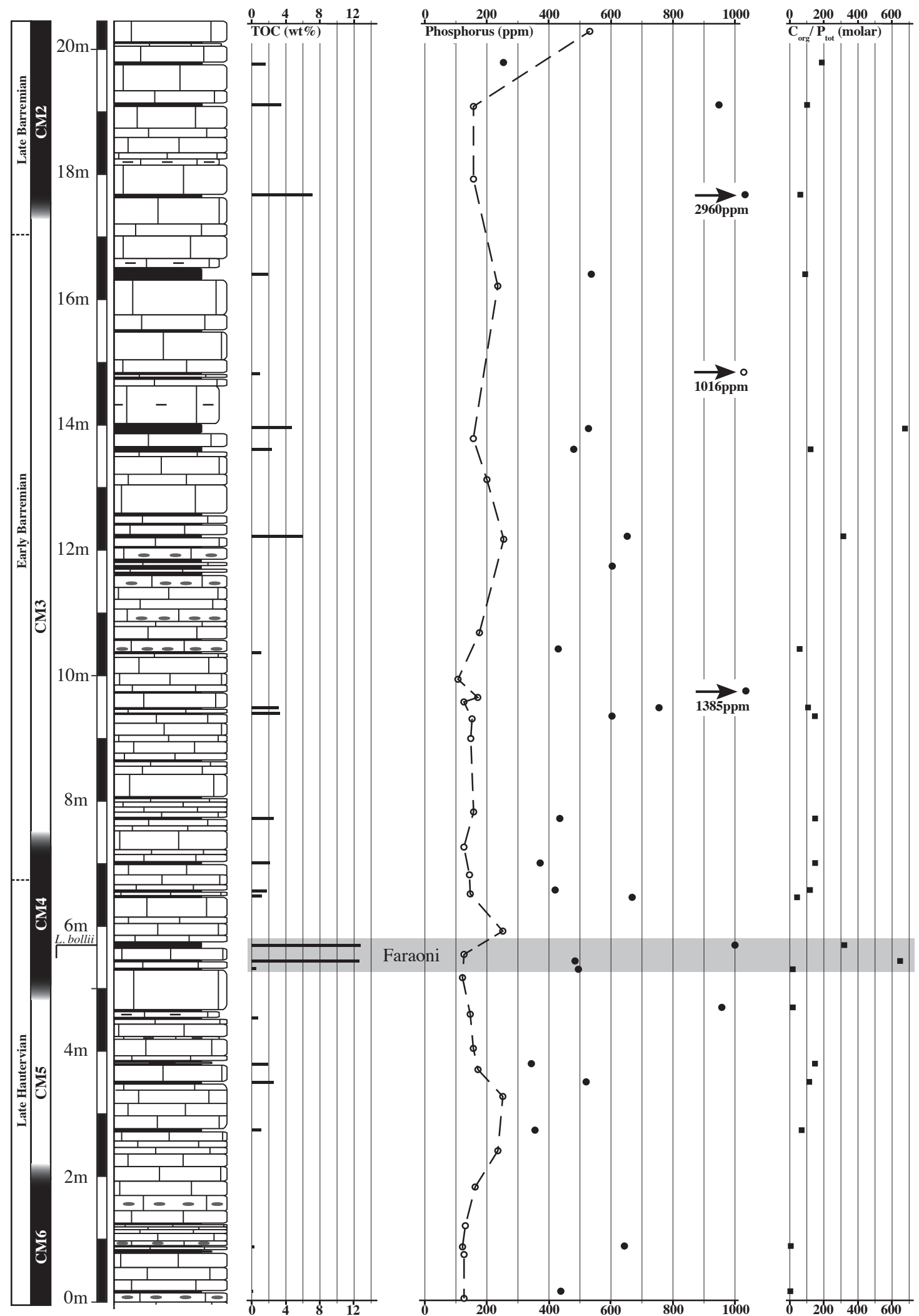

Fig. 2. The Breggia section: TOC contents in mudstone samples, phosphorus contents in carbonate (open circles) and mudstone samples (closed circles), and calculated $\mathrm{C}_{\mathrm{org}}: \mathrm{P}_{\text {tot }}$ molar ratios. The grey band indicates the position of the Faraoni level. The magnetostratigraphy is after Channel et al. (1993). 


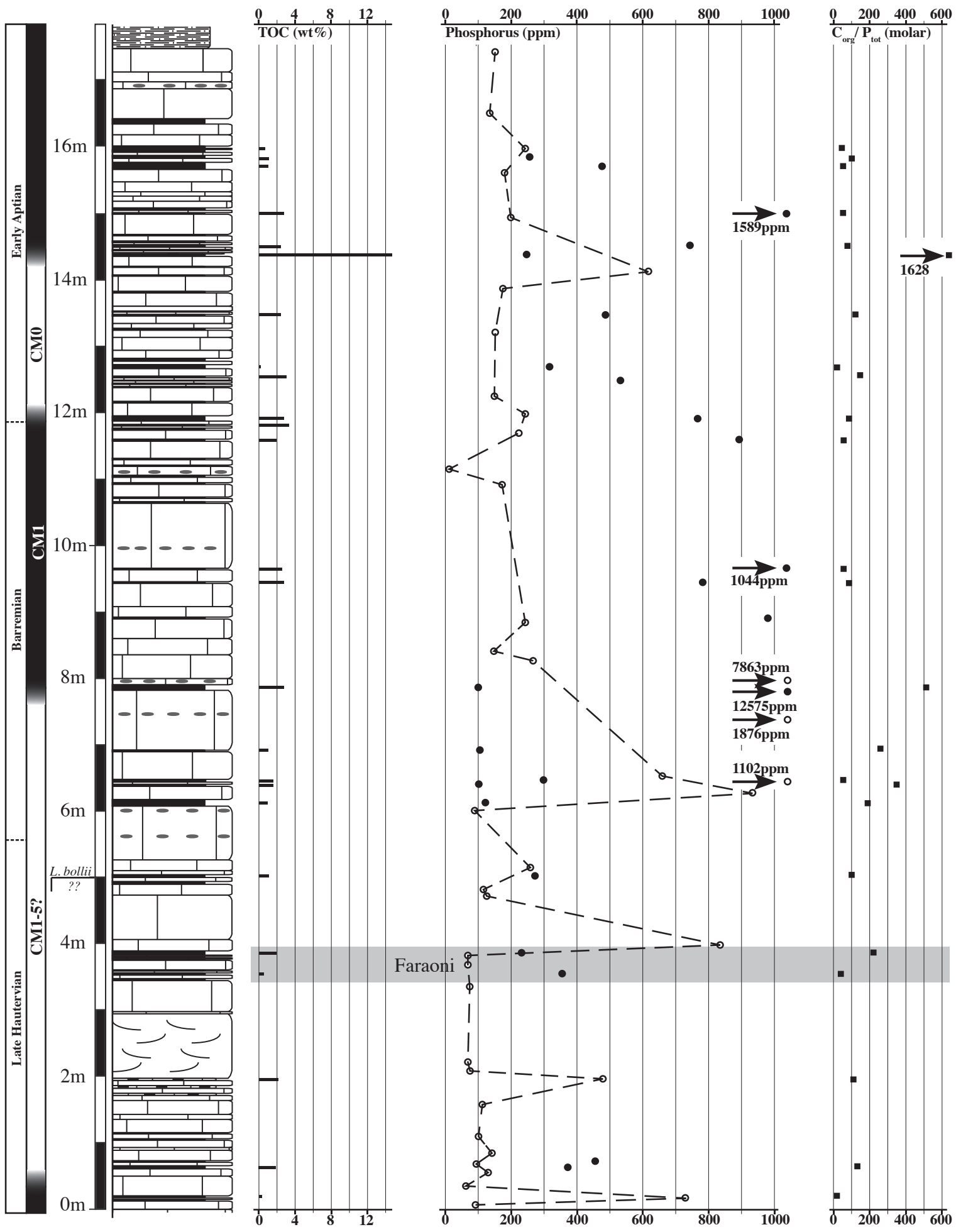

Fig. 3. The Capriolo section: TOC contents in mudstone samples, phosphorus contents in carbonate (open circles) and mudstone samples (closed circles), and calculated $\mathrm{C}_{\text {org }}: \mathrm{P}_{\text {tot }}$ molar ratios. The grey band indicates the position of the Faraoni level. The magnetostratigraphy is after Channel et al. (1987) and Channel and Erba (1992). 

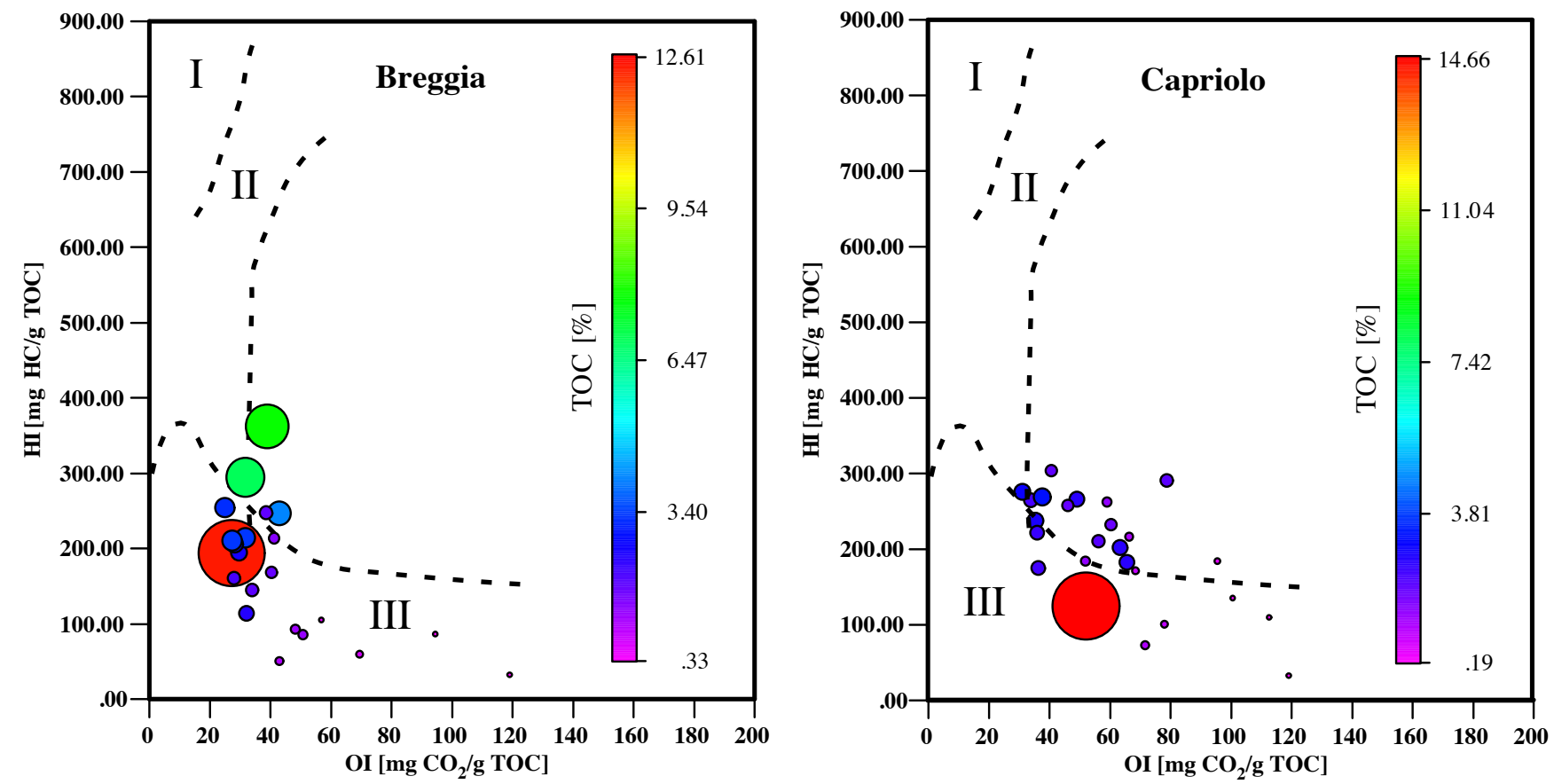

Fig. 4. Hydrogen index (HI) values versus oxygen index (OI) values in a Van Krevelen-type diagram for mudstone samples from the Breggia and Capriolo sections.

\section{Discussion}

\subsection{Organic-carbon contents and preservation}

TOC contents reach values above $10 \mathrm{wt} \%$ in two mudstone layers below the Hauterivian-Barremian boundary in the Breggia section and in one layer within the lower Aptian interval in the Capriolo section (Figs. 2 and 3). All other measured intervals possess TOC contents below 7 and $4 \mathrm{wt} \%$, for the Breggia and Capriolo sections, respectively. These values are generally lower than the values measured for the Faraoni interval in central Italy (e.g., Baudin, 2005), whereas they are higher than the ones measured in organic-rich layers immediately underneath the Selli Level in central Italy (Stein et al., 2011). In comparison to the Breggia section, the TOC values in Capriolo are generally lower. In addition to original differences in TOC values between the two sections, this may also be related to a higher degree of tectonic overprint in the Capriolo section. This may also be indicated by the slightly higher $T_{\max }$ values in Capriolo (average value $=430^{\circ}$ ) relative to Breggia $\left(\right.$ average value $\left.=427^{\circ}\right)($ Espitalié et al., 1985) .

The HI and OI values plot within or nearby the type-III field (Fig. 4), and no real trends are discernable between TOC contents and HI/OI values, except for very low values underneath $0.5 \mathrm{wt} \%$, which tend to have very low $\mathrm{HI}$ and higher OI values. These values suggest that preserved organic matter in both sections is partly altered by its tectonic history and aerial exposure, but may also include a terrestrial component. The levels close to the Hauterivian-Barremian boundary in the Breggia and Capriolo sections show systematically lower HI values than the Faraoni level in central Italy (with values up to 600; Baudin, 2005).

\subsection{Phosphorus contents and $\mathrm{C}_{\text {org }}: \mathbf{P}_{\text {tot }}$ molar ratios}

Trends in $\mathrm{P}$ burial rates are used as a proxy for temporal changes in the amount of $\mathrm{P}$ transferred into the basin (Föllmi, 1995, 1996; Bodin et al., 2006a), assuming steady-state conditions over time periods covering several residence times of reactive $\mathrm{P}$ in the ocean (approximately $10000-20000 \mathrm{yr}$ in modern oceans; e.g., Filippelli, 2008). Lacking a major detrital fraction, total $\mathrm{P}$ in pelagic carbonate sections may be used as a proxy for reactive $\mathrm{P}$, which was transferred into an authigenic phase, became adsorbed onto reactive mineral surfaces, or remained associated with organic matter (e.g., Ruttenberg, 2004). Under dysaerobic conditions, buried P may be preferentially released and returned to bottom waters, and $\mathrm{P}$ burial rates may tend to lower, thereby masking the initial P flux rates into the basin (e.g., Slomp et al., 2004; Mort et al., 2007). Evidence for this is provided by the $\mathrm{C}_{\text {org }}: \mathrm{P}_{\text {tot }}$ molar ratios in organic-rich layers, which tend to be significantly higher than the Redfield ratio (106:1) under dysaerobic conditions (e.g., Algeo and Ingall, 2007; Mort et al., 2007).

In both sections, $\mathrm{P}$ contents in carbonates and mudstone layers are generally higher in those intervals, where mudstone layers are more frequent and characterised by higher TOC contents (Figs. 2 and 3). The overall $\mathrm{P}$ contents are 

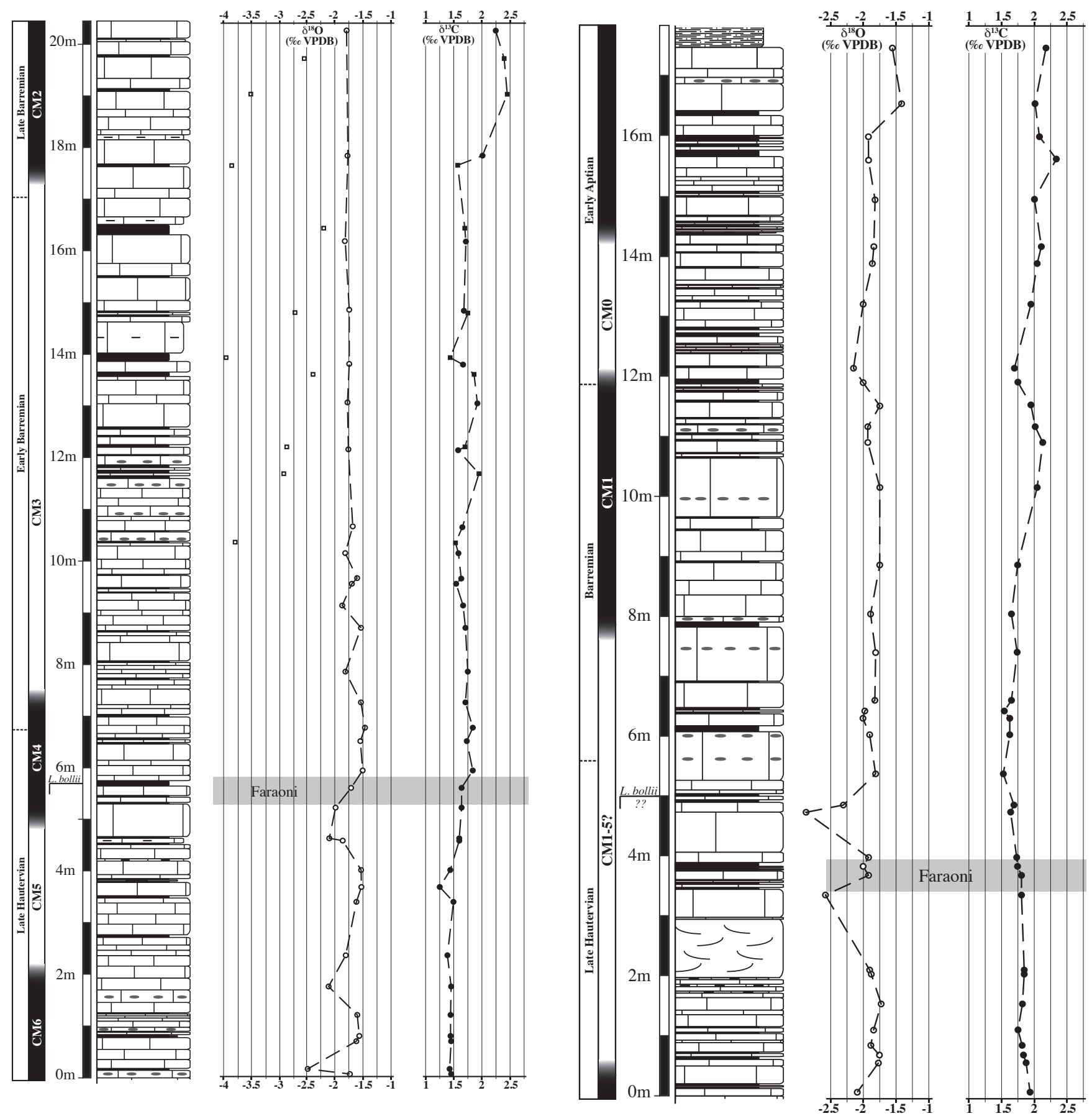

Fig. 5. The Breggia section: stable-carbon and oxygen-isotope values for carbonate (open and closed circles) and mudstone samples (open and closed rectangles).

relatively low and comparable to those of other sections in the Maiolica Formation (e.g., Gorgo a Cerbara, Stein et al., 2011) or in older intervals of the Maiolica Formation in the same sections (Westermann, 2010). The general trend in $\mathrm{P}$ contents in carbonate samples are comparable to those compiled by Bodin et al. (2006a) and Föllmi (1995).

Fig. 6. The Capriolo section: stable carbon and oxygen isotope values for carbonate samples.

In the Breggia section, the $\mathrm{C}_{\mathrm{org}}: \mathrm{P}_{\text {tot }}$ molar ratios are larger than 300 for mudstone interlayers with the highest TOC values (exception is a mudstone layer just above the boundary between the lower and upper Barremian intervals: Fig. 2). In the Capriolo section, this relationship holds only for one mudstone interlayer within the lower Aptian interval. These departures from the Redfield ratio of 106 are interpreted as 

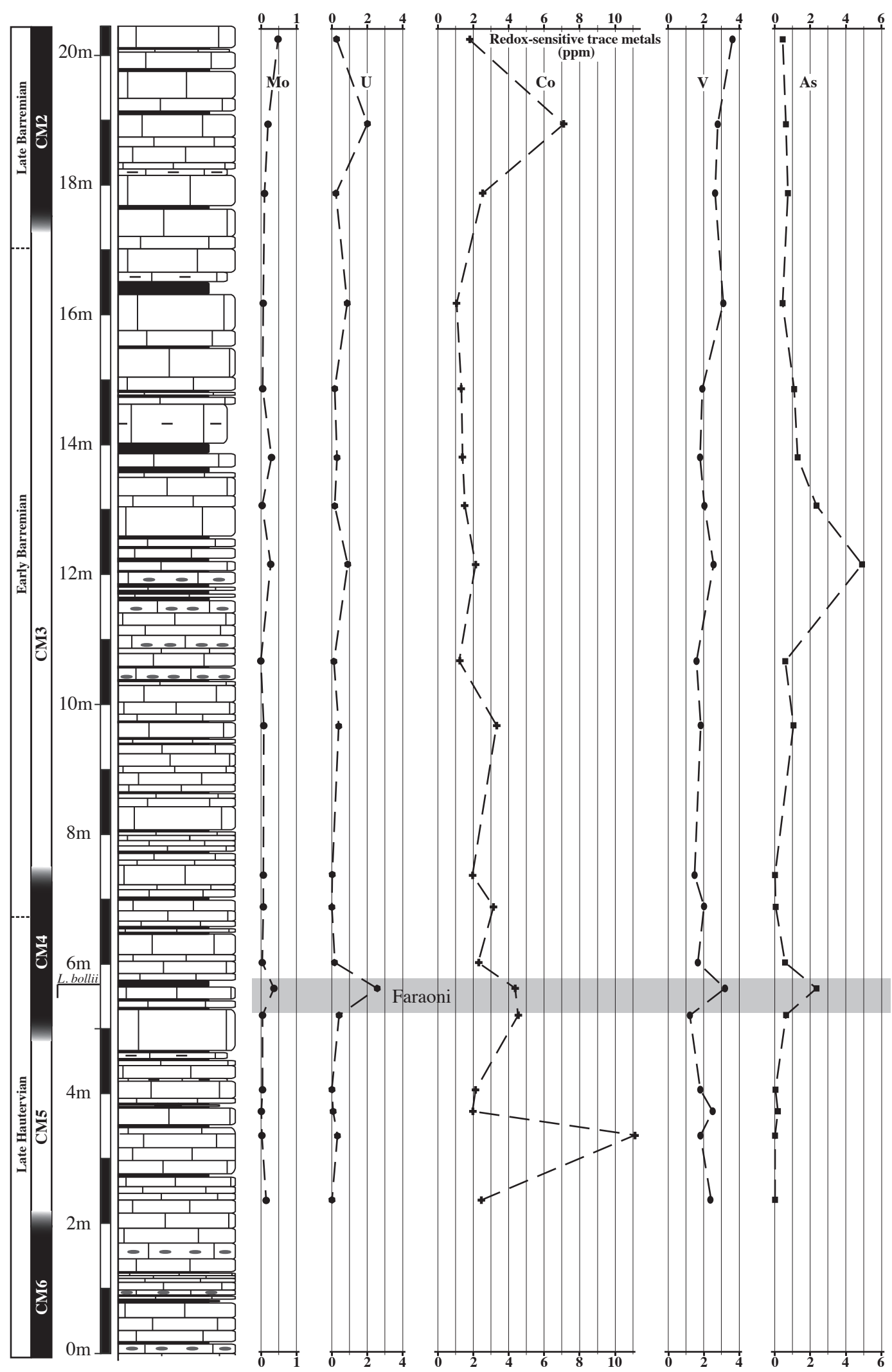

Fig. 7. The Breggia section: redox-sensitive trace-metal distributions for molybdenum (Mo), uranium (U), cobalt (Co), vanadium (V) and arsenic (As) in carbonate samples. 

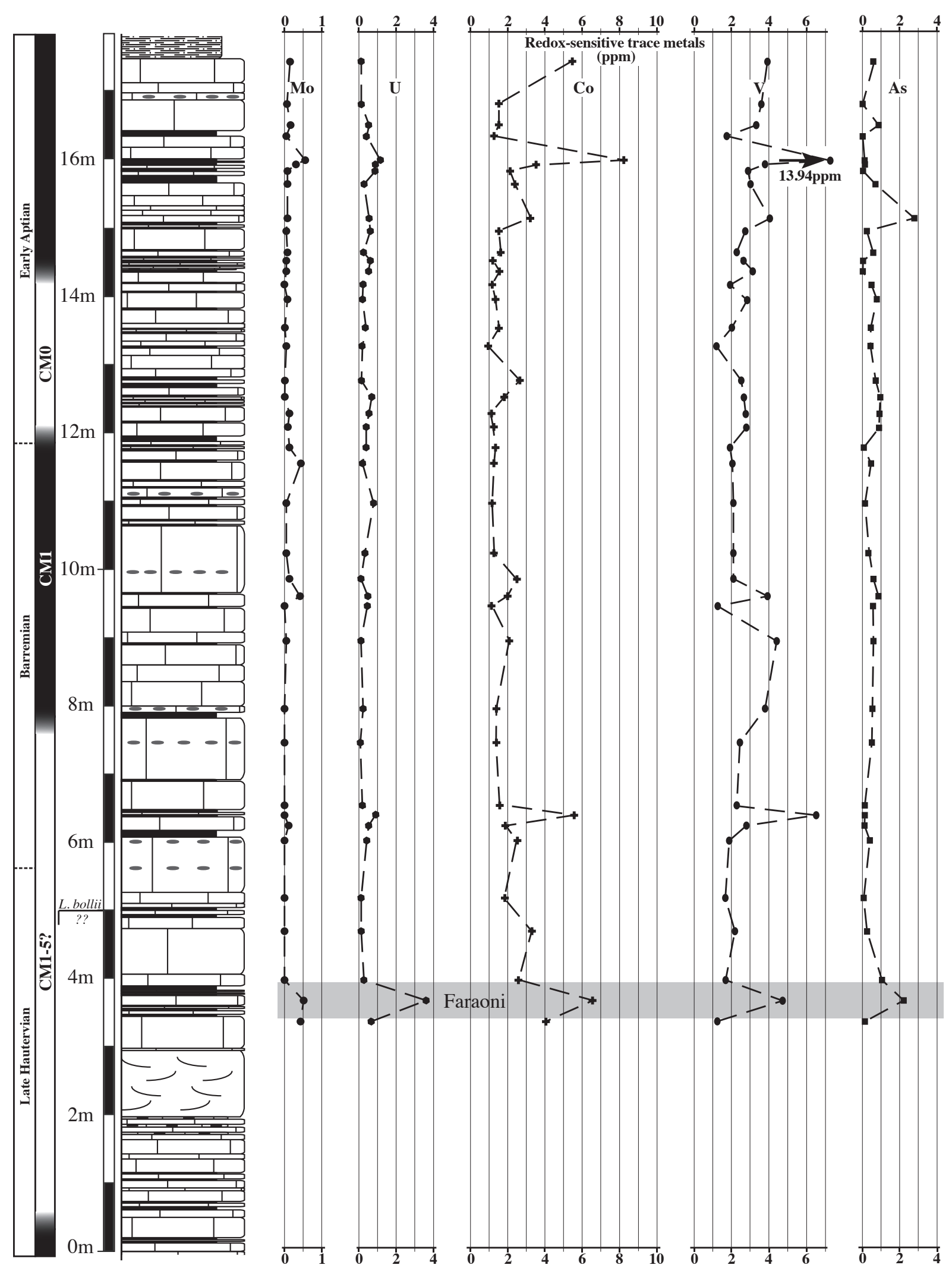

Fig. 8. The Capriolo section: redox-sensitive trace-metal distributions for molybdenum (Mo), uranium (U), cobalt (Co), vanadium (V) and arsenic (As) in carbonate samples. 
an indication of oxygen-depletion and preferential $\mathrm{P}$ release during the deposition of these layers.

\subsection{Stable carbon isotopes}

In the Breggia section, the general trend is similar to trends in other sections of the central and northern Tethys (Fig. 9). Minimal $\delta^{13} \mathrm{C}$ values in the upper Hauterivian interval, the increase in the uppermost Hauterivian and lowermost Barremian interval, the trend to slightly more negative values in the lower part of the lower Barremian interval, the positive trend followed by the negative trend in the upper part of the lower Barremian interval, and the sharp increase in $\delta^{13} \mathrm{C}$ values in the lower part of the upper Barremian interval are well correlated (Godet et al., 2006).

The long-term trends in the $\delta^{13} \mathrm{C}$ record in the Capriolo section appear also correlatable, with minimal values near the Hauterivian-Barremian boundary, followed by a trend towards more positive values, which are typical for the late Barremian. The $\delta^{13} \mathrm{C}$ record seems to confirm that most of the lower Barremian interval is missing (Fig. 9). The trend towards more negative values during the upper part of the Barremian interval and the minimum in the $\delta^{13} \mathrm{C}$ record near the Barremian-Aptian boundary is also known from the Cismon Apticore in northeastern Italy (Erba et al., 1999), the Gorgo a Cerbara section in central Italy (Godet et al., 2006; Sprovieri et al., 2006), and the Angles section in southeastern France (Wissler et al., 2002; Godet et al., 2006).

It is clear, from the correlations shown in Fig. 9, that the overall accumulation rates of the Breggia and Capriolo sections are much lower compared to those of other sections from the central and northern Tethyan realms.

\subsection{Redox-sensitive trace-element records}

Stratigraphic distributions of RSTE (here: Mo, U, Co, V and As) and enrichments therein are widely used as a tracer of the presence and intensity of oxygen-depletion within the water column during sediment deposition. The here-investigated suite of RSTE appears preferentially in dissolved form under oxidizing conditions, and tends to form organo-metal complexes or precipitate as oxides, hydroxides and sulfides under anoxic conditions (Algeo and Maynard, 2004; Tribovillard et al., 2006; Brumsack, 2006; Bodin et al., 2007; Westermann et al., 2010).

The RSTE contents discussed here have been measured on carbonate samples, and the absolute values are generally depleted relative to those for post-Archean average shale (PAAS; $\mathrm{Mo}=1 \mathrm{ppm}, \mathrm{U}=2.8 \mathrm{ppm}, \mathrm{Co}=17 \mathrm{ppm}$, $\mathrm{V}=107 \mathrm{ppm}$, As = 1.5 ppm; Taylor and McLennan, 1985, 1995). This implies that enrichments in RSTE relative to the background values in the carbonates of both sections are not of a magnitude, which would allow for the definite identification of dysaerobic or anaerobic conditions. It is only in combination with the other parameters used here (TOC, $\mathrm{C}_{\text {org }}: \mathrm{P}_{\text {tot }}$ ratios) that certain observations can be made.

The RSTE enrichments in carbonates associated with mudstone layers underneath the Hauterivian-Barremian boundary in the Breggia section go along with high TOC values and elevated $\mathrm{C}_{\text {org }}: \mathrm{P}_{\text {tot }}$ ratios (Figs. 2 and 7). To a lesser extent, the same coincidence is observed for the middle part of the lower Barremian interval in the Breggia section. For the Capriolo section, similar RSTE enrichments are observed for the carbonates near the mudstone layers underneath the Hauterivian-Barremian boundary; TOC and $\mathrm{C}_{\text {org }}: \mathrm{P}_{\text {tot }}$ ratios of the same layers, are, however, not exceptionally high. The carbonates around a mudstone layer with high TOC and $\mathrm{C}_{\text {org }}: \mathrm{P}_{\text {tot }}$ ratio within the lower Aptian interval are not enriched in RSTE (Figs. 3 and 8). Carbonate samples above this level are more enriched in RSTE, but the associated mudstone layers are not exceptionally enriched in TOC and their $\mathrm{C}_{\text {org }}: \mathrm{P}_{\text {tot }}$ ratio is not increased relative to the Redfield ratio of 106:1.

For the Breggia section, these observations imply that anaerobic conditions may have prevailed during mudstone deposition in the latest Hauterivian and in the middle part of the early Barremian. For the Capriolo section, the data are less conclusive, and substantial oxygen depletion can only be postulated for the latest Hauterivian and eventually also for the early Aptian. For the remainder of the laminated organicrich mudstone layers, depositional conditions were dysaerobic, rather than anaerobic. Given the paleogeographic proximity of both sections, the aforementioned discrepancy in terms of bottom-water oxygenation may reflect the development of local anaerobic pockets within larger dysaerobic bottom-water masses. If so, this may be an expression of local differences in topography, bottom-water salinity, and primary productivity.

\subsection{The Faraoni oceanic anoxic episode}

In the Breggia section, the two organic-rich mudstone layers with TOC contents over $12 \mathrm{wt} \%$, RSTE enrichment and $\mathrm{C}_{\text {org }}: \mathrm{P}_{\text {tot }}$ ratios over 300 near the base of magnetochron CM4 are identified as an equivalent of the Faraoni level of central Italy. The correlation is confirmed by the nannofossil assemblages in the organic-rich mudstone interlayers, which consist of abundant large-sized Assipetra terebrodentarius, Assipetra infracretacea, and Zeugrhabdotus embergeri, and the last occurrence of Lithraphidites bollii (cf. Tremolada et al., 2009).

In the Capriolo section, the identification of the Faraoni level is less conclusive with regards to the geochemical tracers. There are no levels within the upper Hauterivian interval, which are particularly enriched in TOC or P (relative to $C_{\text {org }}$ ). A level enriched in RSTE right underneath the last occurrence of Lithraphidites bollii is taken as the equivalent of the Faraoni level. This is confirmed by the presence of 


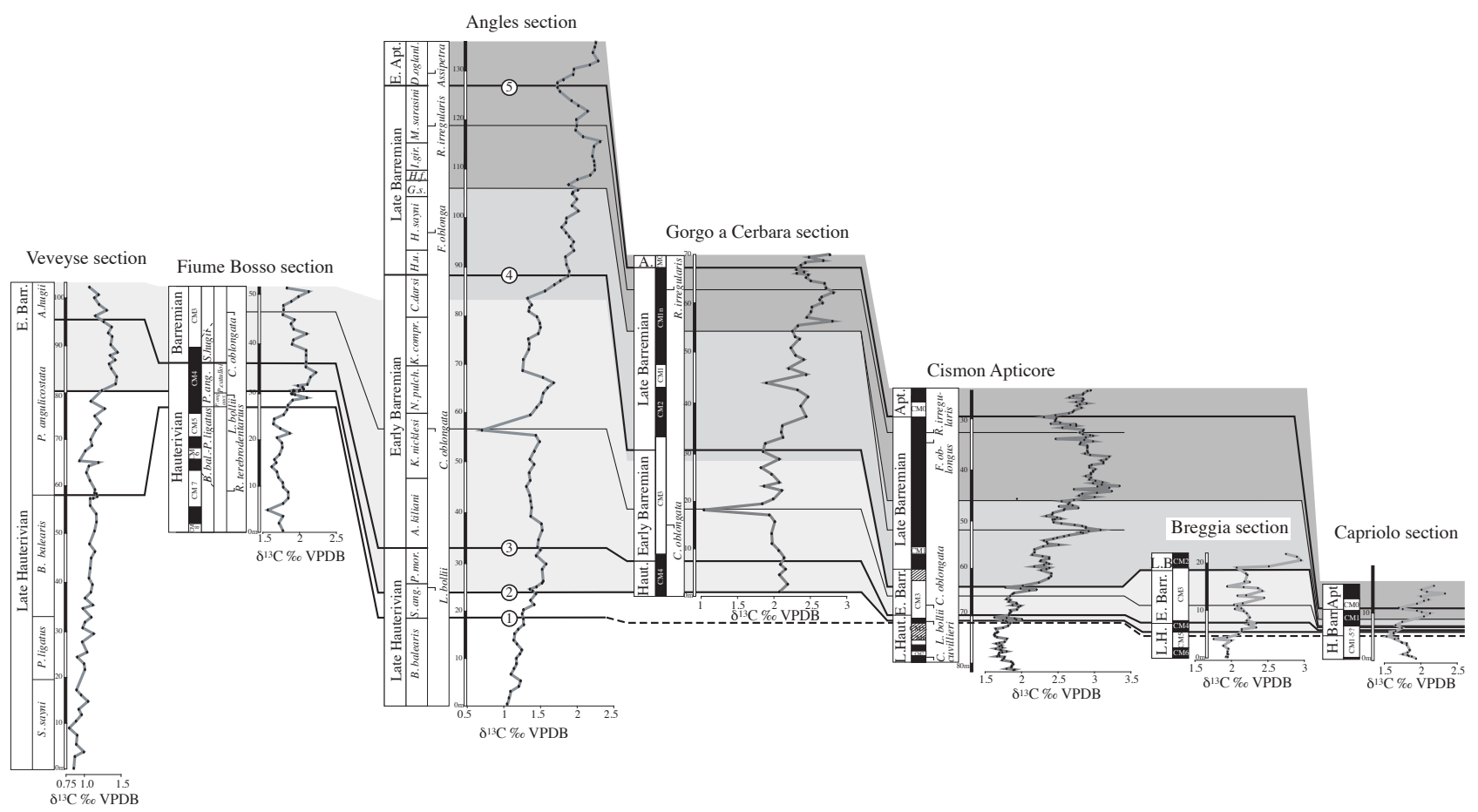

Fig. 9. Correlation of the $\delta^{13} \mathrm{C}$ records of the Veveyse de Châtel Saint Denis, Fiume Bosso, Angles, Gorgo a Cerbara and Cismon Apticore sections and cores (modified from Godet et al., 2006) and the Breggia and Capriolo records.

the same nannofossil species as in the Faraoni level of the Breggia section.

The Faraoni level is preceded by organic-rich layers, which appear approximately 5 and $3 \mathrm{~m}$ below the Faraoni level in the Breggia and Capriolo sections, respectively. The Faraoni level is also succeeded by a series of organic-rich mudstone interlayers, which extend well into the Barremian. These interlayers are thinner than the layers associated with the Faraoni event and their TOC contents are not higher than $2 \mathrm{wt} \%$. Furthermore, they lack major departures in RSTE contents and $\mathrm{C}_{\text {org }}: \mathrm{P}_{\text {tot }}$ ratios, which suggests that they are the product of dysaerobic rather than anaerobic conditions.

Overall, it appears that the Faraoni event is not a singular event, but rather a culminating episode of anaerobic conditions within a longer time interval of periodically resurfacing dysaerobic conditions leading to enhanced organicmatter preservation and/or diminishing carbonate deposition (cf. Bodin et al., 2006a).

\subsection{Temporal pattern in organic-matter preservation during the latest Hauterivian to earliest Aptian time interval}

In order to quantify the relative importance of organic-matter deposition and preservation per time unit, we established a density profile of the organic-rich mudstone layers. The profile was calculated as

OML density $=\Sigma q_{\mathrm{OML}} / t$ where OML stands for organic-rich mudstone layer, $t$ for time unit (corresponding to entire or parts of magnetochrons in the case of the Breggia and Capriolo sections; in my) and $q_{\mathrm{OML}}$ as parametrization for the thickness (h) of each layer, where $q_{\mathrm{OML}}=1(\mathrm{~h}<2 \mathrm{~cm}), q_{\mathrm{OML}}=2$ $(2 \mathrm{~cm}<\mathrm{h}<4 \mathrm{~cm}), \quad q_{\mathrm{OML}}=3 \quad(4 \mathrm{~cm}<\mathrm{h}<6 \mathrm{~cm}), \quad q_{\mathrm{OML}}=4$ $(6 \mathrm{~cm}<\mathrm{h}<8 \mathrm{~cm}), q_{\mathrm{OML}}=5(8 \mathrm{~cm}<\mathrm{h}<10 \mathrm{~cm})$, etc. Thicknesses greater than $20 \mathrm{~cm}$ have not been observed. $\Sigma q_{\mathrm{OML}}$ corresponds to the sum of $q_{\mathrm{OML}}$. For example, if an interval corresponding to 2 my has five organic-rich interlayers with thicknesses of $1,5,11,2$ and $3 \mathrm{~cm}$, respectively, the OML density would correspond to $(1+3+6+1+2) / 2=6.5$ for this interval.

The results of this quantification are shown in Fig. 10 and suggest that periods of increased OML density occurred during the late Hauterivian, latest early Barremian and earliest Aptian. Periods of low OML density are identified for the late Barremian and the time interval just preceding the Selli episode.

\subsection{Comparison with other regions}

For the Tethyan localities of the Faraoni level and its equivalents, the prevalence of anaerobic conditions has been shown based on paleontological (lack of benthos; Baudin, 2005), sedimentological (presence of laminated, organic-rich sediments with TOC values of up to $27 \mathrm{wt} \%$; Baudin, 2005) and geochemical criteria $\left(\mathrm{C}_{\text {org }}-\mathrm{P}_{\text {tot }}\right.$ ratios; excursions in RSTE 


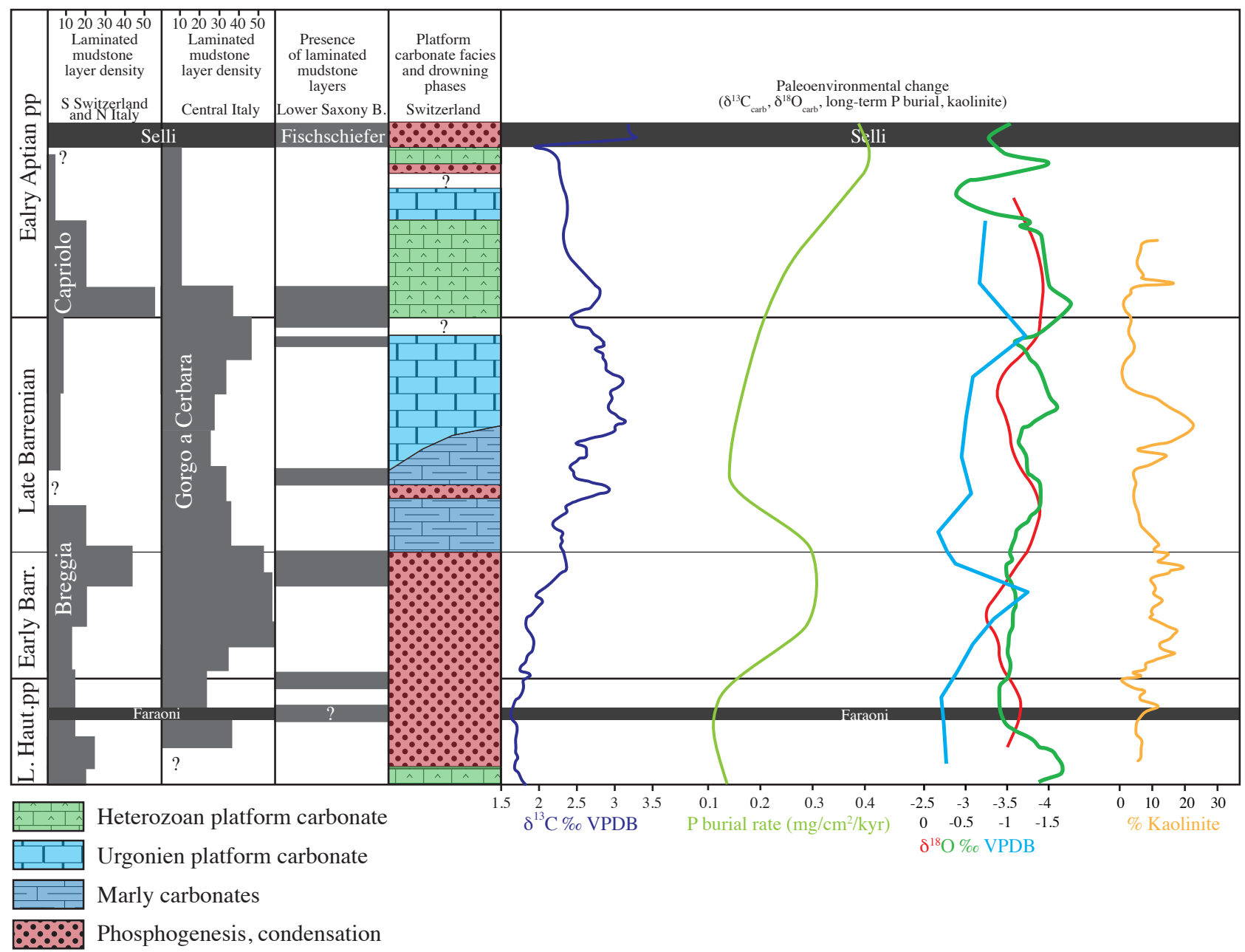

Fig. 10. From left to right: calculated laminated mudstone layer density for the Breggia and Capriolo sections; estimated laminated mudstone layer density for the Gorgo a Cerbara section using the stratigraphic logs from Gorin and Fiet (2000) and Stein et al. (2011); occurrence of laminated mudstone layers in the Lower Saxony Basin: the Barremian and Aptian occurrences are from the basin margin (Mutterlose et al., 2010) and the Hauterivian occurrence from the basin centre (Mutterlose et al., 2009); evolution of the Helvetic segment of the northern Tethyan carbonate platform (modified after Föllmi et al., 2007); $\delta^{13} \mathrm{C}$ record on whole-rock carbonate, from the Cismon outcrop and Cismon Apticore (Menegatti et al., 1998; Erba et al., 1999); low-resolution phosphorus burial record (Föllmi, 1995; Bodin et al., 2006a); $\delta^{18}$ O records from whole-rock carbonate from central Italy (in green; Sprovieri et al., 2006; Stein et al., 2011) and southeast France (in red; Godet et al., 2006; Bodin et al., 2009) and $\delta^{18}$ O record from belemnites from southeastern France (in blue; Bodin et al., 2009); and kaolinite record from southeastern France (Godet et al., 2008).

contents; Bodin et al., 2006a, 2007). The Faraoni anoxic episode coincides also with important evolutionary change in rudists (Masse and Fenerci-Masse, 2008), ammonite faunas (Hoedemaeker and Leereveld, 1995; Company et al., 2005), planktonic foraminifera (Venturati, 2006), radiolaria (O'Dogherty and Guex, 2002; De Wever et al., 2003), and calcareous nannofossils (Company et al., 2005; Tremolada et al., 2009).

With respect to the deposition of the younger, Barremian to lower Aptian organic-rich interlayers, we estimated the OML density for the Gorgo a Cerbara section in central Italy, using the stratigraphic plots of Fiet and Gorin (2000) and
Stein et al. (2011) (Fig. 10). The OML trends are comparable to those obtained from the Breggia and Capriolo sections, with the exception of the uppermost Barremian inter$\mathrm{val}$, which is distinctly richer in organic-rich interlayers relative to the Capriolo section. Interestingly, a good correspondence is also given between the OML density curves for the central Tethys and the presence of laminated mudstone layers in the Lower Saxony Basin (Mutterlose et al., 2009; 2010). We searched for further basinal records of this time interval; and indeed, the presence of organic-rich mudstone interlayers is known from different DSDP and ODP Sites from the central and northern Atlantic (e.g., Weissert, 1981a; Stein 
et al., 1988). The current age models for those deposits do, however, not allow for high-resolution correlations.

Besides basin-to-basin correlations, we also observe interdependencies between the periods of enhanced organicmatter preservation and the evolution of the northern Tethyan platform presently outcropping in the Helvetic Alps (Fig. 10). A prolonged phase of platform drowning along the northern Tethyan margin has been documented from the Jura Mountains and Helvetic Alps, which started in the latest Hauterivian and lasted until the late early Barremian (Bodin et al., 2006b; Godet et al., 2010). The oldest possible age for the onset of this drowning episode corresponds to the younger part of the balearis zone (Föllmi et al., 2006, 2007), which predates the onset of the Faraoni anoxic episode.

The early late Barremian is characterised by the deposition of marly carbonate and carbonate-marl succession, which is interrupted by a short phase of condensation and phosphogenesis during the middle late Barremian. Thereafter, Urgonian-type shallow-water carbonates prograde and show the installation of a photozoan carbonate platform. Around the Barremian-Aptian boundary, the deposition of Urgonian carbonate is interrupted by a phase of heterozoan carbonate, marl and sand deposition ("Lower Orbitolina Beds": LOB). On top of the younger Urgonian unit overlying the LOB, a phase of platform drowning is observed, which is followed by heterozoan carbonate deposition ("Upper Orbitolina Beds": UOB), a second drowning phase (corresponding partly in time to the Selli OAE), and further heterozoan carbonate deposition (upper part of the UOB; Fig. 10). The periods of high OML density in the central Tethys realm correspond to periods of platform drowning and/or heterozoan carbonate deposition, whereas the phases of Urgonian photozoan carbonate deposition are correlated with phases of low OML density.

One of the environmental parameters, which may have changed conditions on the platform and in the basin, are variations in the nutrient flux, which interfere both with the composition and efficiency of shallow-water carbonateproducing ecosystems and the pelagic organic-matter export flux. $\mathrm{P}$ accumulation rates established for this time interval go rather well along with the contents measured in the Breggia and Capriolo sections and show an increase across the Hauterivian-Barremian boundary interval and higher values during the early Barremian, followed by lower values during the late Barremian (Bodin et al., 2006a) and higher values again for the early Aptian (Föllmi, 1995).

\subsection{A scenario of paleoenvironmental change during the period from the late Hauterivian to the early Aptian}

During the latest Hauterivian, the central and northern Tethyan basin witnessed short and repetitive phases of dysaerobic conditions and increased organic-matter preservation, whereas on its northern margin, the carbonate platform attached to the southern European margin started to drown. This phase of paleoceanographic change culminated in the Faraoni anoxic episode, which was probably not limited to the Tethyan realm, but may also have left its traces in other basins, probably as far as the Pacific. The late Hauterivian is characterised by a minimum in the Italian $\delta^{18} \mathrm{O}$ whole-rock record (Fig. 10; Weissert and Erba, 2004; Godet et al., 2006; Bodin et al., 2009) and the onset in kaolinite deposition (in southeast France, Godet et al., 2008; Fig. 10; cf. Deconinck and Bernoulli, 1991), which may indicate humid and eventually warmer climate conditions.

The early Barremian is a period of generally increased organic-matter preservation, both in the Tethys as well as in the Boreal Lower Saxony Basin, and likely also in the central and northern Atlantic. The Helvetic and Jurassic segment of the northern Tethyan platform remained largely subjected to a halt in carbonate production, condensation and phosphogenesis, with a culmination in drowning pattern in the later part of the early Barremian (Bodin et al., 2006b). This time period is characterised by increasing $\mathrm{P}$ burial rates and generally high kaolinite depositional rates (Fig. 10), which may indicate continuing humid climate conditions, with an increasing tendency towards the end of the early Barremian (Deconinck and Bernoulli, 1991; Godet et al., 2008). The $\delta^{18} \mathrm{O}$ records in Italy and France show a tendency towards heavier values relative to the late Hauterivian (Sprovieri et al., 2006; Godet et al., 2006; Bodin et al., 2009; Stein et al., 2011), whereas the French belemnite record is characterised by a trend towards lighter values for most of the early Barremian (Bodin et al., 2009; Fig. 10).

The late Barremian is characterised by lower rates of organic-matter preservation in the Tethyan basin and the progressive installation of the Urgonian carbonate platform on the northern Tethyan margin. $\mathrm{P}$ burial rates diminished during this time period and the same is true for kaolinite deposition, with the exception of a maximum in the middle late Barremian. The French $\delta^{18} \mathrm{O}$ records are characterised by relatively positive values for a larger part of the late Barremian, which, in generally, is explained by a tendency towards cooler temperatures (cf. also Ruffell and Batten, 1990).

The renewed increase in organic-matter burial around the Barremian-Aptian boundary goes along with decreasing values in the $\delta^{18} \mathrm{O}$ records and a change towards heterozoan carbonate production on the northern Tethyan platform. Even if the kaolinite record does not show a change in the Vocontian basin record, increases have been established on the adjacent carbonate platform (Godet et al., 2008; Stein et al., 2012). This phase is followed by a decrease in organiccarbon burial and a second episode in Urgonian platform build up. The Selli OAE is finally preceded by a platform drowning phase and a change to heterozoan carbonate production, and goes along with a further platform drowning phase. Common to most of the time periods during which dys- to anaerobic conditions developed is the tendency to warmer and more humid climatic conditions and a corresponding increase in nutrient fluxes (as indicated by $\mathrm{P}$ burial 
rates), which stimulated marine primary productivity and oxygen depletion in deeper waters, and inhibited or even halted carbonate platform growth.

Our reconstruction of paleoenvironmental change during the period from the late Hauterivian to the early Aptian suggests that the Faraoni and Selli OAEs are culminations of longer periods of paleoenvironmental change with a widespread impact, and that the intervening periods of dysto anaerobic conditions in the Tethys were related to those of other basins and had tele-connections with the evolution of the adjacent northern Tethyan carbonate platform. The higher frequency of dys- to anaerobic intervals in the pelagic realm and the vulnerability of the northern Tethyan carbonate platform to drowning during the late Hauterivian, Barremian and early Aptian can be seen as the expression of a dynamic and frequently changing world with regards to its environment and climate.

\section{Conclusions}

We performed a detailed stratigraphic and geochemical analysis of two pelagic sections in southern Switzerland (Breggia) and northern Italy (Capriolo) and suggest that the latest Hauterivian, early Barremian and the Barremian-Aptian boundary interval were times of preferential organic-matter preservation under episodic dys- to anaerobic conditions, whereas the late Barremian and the period following the Barremian-Aptian boundary interval are characterised by a lower density in periods of organic-matter preservation. We compare this evolution to the section of Gorgo a Cerbara (central Italy), to the temporal pattern of organic-matter preservation in the Lower Saxony Basin, and the evolution of the northern Tethyan shallow-water carbonate platform presently preserved in the Helvetic Alps, and observe synchroneity between the dysaerobic to anaerobic episodes in the Tethyan and Boreal Basins and a correspondence to the evolution of the northern Tethyan carbonate platform and its drowning phases. The paleoceanographic changes during the late Hauterivian to early Aptian leading to dys- and anaerobic conditions are likely driven by changes towards warmer and more humid climate conditions and corresponding stronger nutrient fluxes.

This implies that the Faraoni and Selli anoxic episodes do not represent singular events in an otherwise unperturbed world, but are embedded in longer-lasting phases of environmental change preceding and following the anoxic episodes. They are bridged by a series of shorter-lasting dys- and anaerobic episodes during the Barremian and early Aptian, which did not impact the world oceans in the same way as the Selli and probably also the Faraoni episodes. They are, however, more important than hitherto assumed, since a similar record is identified in the Boreal Lower Saxony Basin and since relationships are seen between the frequency and intensity of the dys- to anaerobic episodes and the quality and quantity of carbonate production on the adjacent, northern Tethyan shallow-water carbonate platform.
Acknowledgements. We gratefully acknowledge the advice and assistance in the field of Melody Stein and Stéphane Westermann, the assistance of Tiffany Monnier in the preparation of samples for the ICP-MS analyses, and the expertise of Silvia Gardin for the determination of calcareous nannofossils. We thank the Swiss National Science Foundation for its support during various stages of this research. Financial assistance of the Herbette Foundation is also gratefully acknowledged. Poppe de Boer, Caroline Slomp, Gerald Ganssen, and Henk Brinkhuis are thanked for the organization of the meeting on "Climate and Ocean Dynamics of the Cretaceous Greenhouse World", 26-28 January 2011, Utrecht, and their invitation to contribute this paper. The constructive reviews by Joerg Mutterlose, Caroline Slomp and an anonymous reviewer were very helpful in revising the manuscript.

Edited by: H. Brinkhuis

\section{References}

Algeo, T. J. and Ingall, E.: Sedimentary $\mathrm{C}_{\mathrm{org}}: \mathrm{P}$ ratios, paleocean ventilation, and Phanerozoic atmospheric $\mathrm{pO}_{2}$, Palaeogeogr. Palaeocl., 256, 130-155, 2007.

Algeo, T. J. and Maynard, J. B.: Trace-element behavior and redox facies in core shales of Upper Pennsylvanian Kansas-type cyclothems, Chem. Geol., 206, 289-318, 2004.

Arthur, M. A. and Premoli Silva, I.: Development of widespread organic carbon-rich strata in the mediterranean Tethys, in: Nature and Origin of Cretaceous Carbon-rich Facies, edited by: Schlanger, S. O. and Cita, M. B., Academic Press, London, 7-54, 1982.

Arthur, M. A., Jenkyns, H. C., Brumsack, H. J., and Schlanger, S. O.: Stratigraphy, geochemistry, and paleoceanography of organic carbon-rich Cretaceous sequences, in: Cretaceous Resources, Events and Rhythms: Background and Plans for Research, edited by: Ginsburg, R. N. and Beaudoin, B., NATO ASI Series, C 304, 75-119, 1990

Baudin, F.: A late Hauterivian short-lived anoxic event in the Mediterranean Tethys: the "Faraoni event", Compt. Rend. Geosc., 337, 1532-1540, 2005.

Baudin, F., Deconinck, J.-F., Sachsenhofer, R. F., Strasser, A., and Arnaud, H.: Organic geochemistry and clay mineralogy of Lower Cretaceous sediments from Allison and Resolution Guyots (Sites 865 and 866), Mid-Pacific Mountains, in: Proceedings of the Ocean Drilling Program, Scientific Results 143, edited by: Winterer, E. L., Sager, W. W., Firth, J. V., and Sinton, J. M., College Station, 173-196, 1995.

Baudin, F., Faraoni, P., Marini, A., and Pallini, G.: Organic matter characterisation of the "Faraoni Level" from northern Italy (Lessini Mountains and Trento Plateau): comparison with that from Umbria-Marche Apennines, Palaeopelagos, 7, 41-51, 1997.

Baudin, F., Bulot, L. G., Cecca, F., Coccioni, R., Gardin, S., and Renard, M.: Un équivalent du "Niveau Faraoni" dans le bassin du Sud-Est de la France, indice possible d'un événement anoxique fini-hauterivien étendu à la Téthys méditerranéenne, Bull. Soc. Géol. France, 170, 487-498, 1999.

Baudin, F., Cecca, F., Galeotti, S., and Coccioni, R.: Palaeoenvironmental controls of the distribution of organic matter within 
a $\mathrm{C}_{\text {org }}$-rich marker bed (Faraoni level, uppermost Hauterivian, central Italy), Eclog. Geol. Helv., 95, 1-13, 2002.

Bellanca, A., Erba, E., Neri, R., Premoli Silva, I., Sprovieri, M., Tremolada, F., and Verga, D.: Palaeoceanographic significance of the Tethyan "Livello Selli" (early Aptian) from the Hybla Formation, northwestern Sicily: biostratigraphy and high-resolution chemostratigraphic records, Palaeogeogr. Palaeocli., 185, 175196, 2002.

Bersezio, R., Erba, E., Gorza, M., and Riva, A.: BerriasianAptian black shales of the Maiolica formation (Lombardian basin, southern Alps, northern Italy): local to global events, Palaeogeogr. Palaeocli., 180, 253-275, 2002.

Bodin, S., Godet, A., Föllmi, K. B., Vermeulen, J., Arnaud, H., Strasser, A., Fiet, N., and Adatte, T.: The late Hauterivian Faraoni oceanic anoxic event in the western Tethys: evidence from phosphorus burial rates, Palaeogeogr. Palaeocli., 235, 245264, 2006a.

Bodin, S., Godet, A., Vermeulen, J., Linder, P., and Föllmi K. B.: Biostratigraphy, sedimentology and sequence stratigraphy of the latest Hauterivian - early Barremian drowning episode of the Northern Tethyan margin (Altmann Member, Helvetic nappes, Switzerland), Eclog. Geol. Helv., 99, 157-174, 2006 b.

Bodin, S., Godet, A., Matera, V., Steinmann, P., Vermeulen, J., Gardin, S., Adatte, T., and Föllmi, K. B.: Enrichment of redoxsensitive trace metals ( $\mathrm{U}, \mathrm{V}, \mathrm{Mo}, \mathrm{As})$ associated with the late Hauterivian Faraoni oceanic anoxic event, Int. J. Earth Sci., 96, 327-341, 2007.

Bodin, S., Fiet, N., Godet, A., Matera, V., Westermann, S., Clément, A., Janssen, N. M. M., Stille, P., and Föllmi, K. B.: Early Cretaceous (late Berriasian to early Aptian) palaeoceanographic change along the northwestern Tethyan margin (Vocontian Trough, southeastern France): $\delta^{13} \mathrm{C}, \delta^{18} \mathrm{O}$ and $\mathrm{Sr}$-isotope belemnite and whole-rock records, Cret. Res., 30, 1247-1262, 2009.

Bralower, T. J., Arthur, M. A., Leckie, R. M., Sliter, W. V., Allard, D. J., and Schlanger, S. O.: Timing and paleoceanography of oceanic dysoxia/anoxia in the late Barremian to early Aptian (Early Cretaceous), Palaios, 9, 335-369, 1994.

Bralower, T. J., Premoli Silva, I., and Malone, M. J.: New evidence for abrupt climate change in the Cretaceous and Paleogene: an Ocean Drilling Program expedition to Shatsky Rise, northwest Pacific, GSA Today, 12, 4-10, 2002.

Bréhéret, J. G.: Episodes de sédimentation riche en matière organique dans les Marnes Bleues d'âge Aptien et Albien de la partie pélagique du bassin Vocontien, Bull. Soc. Géol. France, 8, 349-356, 1988.

Brumsack, H.-J.: The trace metal content of recent organic carbonrich sediments: Implications for Cretaceous black shales formation, Palaeogeogr. Palaeocl., 232, 344-361, 2006.

Busnardo, R., Charollais, J., Weidmann, M., and Clavel, B.: Le Crétacé inférieur de la Veveyse de Châtel (Ultrahelvétique des Préalpes externes; canton de Fribourg, Suisse), Rev. Paléobiol., 22, 1-174, 2003.

Channell, J. E. T. and Erba, E.: Early Cretaceous polarity chrons CM0 to CM11 recorded in northern Italian land sections near Brescia, Earth Planet. Sci. Lett., 108, 161-179, 1992.

Channell, J. E. T., Bralower, T. J., and Grandesso, P.: Biostratigraphic correlation of Mesozoic polarity chrons CM1 to CM23 at Capriolo and Xausa (Southern Alps, Italy), Earth Planet. Sci.
Lett., 85, 203-221, 1987.

Channell, J. E. T., Erba, E., and Lini, A.: Magnetostratigraphic calibration of the late Valanginian carbon isotope event in pelagic limestones from northern Italy and Switzerland, Earth Planet. Sci. Lett., 118, 145-166, 1993.

Channell, J. E. T., Cecca, F., and Erba, E.: Correlations of Hauterivian and Barremian (Early Cretaceous) stage boundaries to polarity chrons, Earth Planet. Sci. Lett., 134, 125-140, 1995.

Channell, J. E. T., Erba, E., Muttoni, G., and Tremolada, F.: Early Cretaceous magnetic stratigraphy in the Apticore drill core and adjacent outcrop at Cismon (Southern Alps, Italy), and correlation to the proposed Barremian-Aptian boundary stratotype, GSA Bulletin, 112, 1430-1443, 2000.

Cecca, F., Marini, A., Pallini, G., Baudin, F., and Begouen, V.: A guide-level of the uppermost Hauterivian (Lower Cretaceous) in the pelagic succession of Umbria-Marche Apennines (Central Italy): the Faraoni Level, Riv. Ital. Paleont. Stratigr., 99, 551568, 1994.

Cecca, F., Galeotti, S., Coccioni, R., and Erba, E.: The equivalent of the "Faraoni Level" (uppermost Hauterivian, Lower Cretaceous) recorded in the eastern part of Trento Plateau (Venetian southern Alps, Italy), Riv. Ital. Paleont. Stratigr., 102, 417-424, 1996.

Coccioni, R., Nesci, O., Tramontana, M., Wezel, F.-C., and Moretti, E.: Descrizione di un livello-guida "radiolaritico-bituminosoittiolitico" alla base delle Marne a Fucoidi nell'Appennino umbro-marchigiano, Boll. Soc. Geol. Italia, 106, 183-192, 1987.

Coccioni, R., Baudin, F., Cecca, F., Chiari, M., Galeotti, S., Gardin, S., and Salvini, G.: Integrated stratigraphic, palaeontological, and geochemical analysis of the uppermost Hauterivian Faraoni Level in the Fiume Bosso section, Umbria-Marche Apennines, Italy, Cret. Res., 19, 1-23, 1998.

Coccioni, R., Luciani, V., and Marsili, A.: Cretaceous oceanic anoxic events and radially elongated chambered planktonic foraminifera: paleoecological and paleoceanographic implications, Palaeogeogr. Palaeocli., 235, 66-92, 2006.

Company, M., Aguado, R., Sandoval, J., Tavera, J. M., Jiménez de Cisneros, C., and Vera, J. A.:. Biotic changes linked to a minor anoxic event (Faraoni level, latest Hauterivian, Early Cretaceous), Palaeogeogr. Palaeocli., 224, 186-199, 2005.

Deconinck, J.-F. and Bernoulli, D.: Clay mineral assemblages of Mesozoic pelagic and flysch sediments of the Lombardian Basin (Southern Alps): implications for palaeotectonics, palaeoclimate and diagenesis, Geol. Rundsch., 80, 1-17, 1991.

De Wever, P., O’Dogherty, L., Caridroit, M., Dumitrica, P., Guex, J., Nigrini, C., and Caulet, J.-P.: Diversity of radiolarian families through time, Bull. Soc. géol. France, 174, 453-469, 2003.

Eaton, A. D., Clesceri, L. S., and Greenberg, A. E.: Standard Methods for the Examination of Water and Wastewater, 19th Edition, American Public Health Association, USA, 4113-4114, 1995

Erba, E., Channell, J. E. T., Claps, M., Jones, C., Larson, R., Opdyke, B., Premoli-Silva, I., Riva, A., Salvini, G., and Torricelli, S.: Integrated stratigraphy of the Cismon Apticore (southern Alps, Italy): a "reference section" for the Barremian-Aptian interval at low latitudes, J. Foram. Res., 29, 371-391, 1999.

Erba, E., Bottini, C., Weissert, H. J., and Keller, C. E.: Calcareous nannoplankton response to surface-water acidification around oceanic anoxic event 1a, Science, 329, 428-432, 2010.

Espitalié, J., Deroo, G., and Marquis, F.: La pyrolyse Rock-Eval et ses applications, Rev. Inst. Français Pétr., 40, 563-579, 1985. 
Faraoni, P., Marini, A., Pallini, G., and Pezzoni, N.: The Maiolica Formation of the Lessini Mountains and central Apennines (northeastern and central Italy): a correlation based on new biolithostratigraphical data from the uppermost Hauterivian, Palaeopelagos, 6, 249-259, 1997.

Fiet, N. and Gorin, G.: Lithological expression of Milankovitch cyclicity in carbonate-dominated, pelagic, Barremian deposits in central Italy, Cret. Res., 21, 457-467, 2000.

Filippelli, G. M.: The global phosphorus cycle: past, present, and future, Elements, 4, 89-95, 2008.

Föllmi, K. B.: 160 m.y. record of marine sedimentary phosphorus burial: Coupling of climate and continental weathering under greenhouse and icehouse conditions, Geology, 23, 859-862, 1995.

Föllmi, K. B.: The phosphorus cycle, phosphogenesis and marine phosphate-rich deposits, Earth-Sci. Rev., 40, 55-124, 1996.

Föllmi, K. B., Godet, A., Bodin, S., and Linder, P.: Interactions between environmental change and shallow-water carbonate buildup along the northern Tethyan margin and their impact on the Early Cretaceous carbon-isotope record, Paleoceanography, 21, PA4211, doi:10.1029/2006PA001313, 2006.

Föllmi, K. B., Bodin, S., Godet, A., Linder, P., and van de Schootbrugge, B.: Unlocking paleo-environmental information from Early Cretaceous shelf sediments in the Helvetic Alps: stratigraphy is the key!, Swiss J. Geosci., 100, 349-369, 2007.

Godet, A., Bodin, S., Föllmi, K. B., Vermeulen, J., Gardin, S., Fiet, N., Adatte, T., Berner, Z., Stüben, D., and van de Schootbrugge, B.: Evolution of the marine stable carbon-isotope record during the Early Cretaceous: a focus on the late Hauterivian and Barremian in the Tethyan realm, Earth Planet. Sci. Lett., 242, 254271, 2006

Godet, A., Bodin, S., Adatte, T., and Föllmi, K. B.: Platforminduced clay-mineral fractionation along a northern Tethyan basin-platform transect: implications for the interpretation of Early Cretaceous climate change (late Hauterivian-early Aptian), Cret. Res., 29, 830-847, 2008.

Godet, A., Föllmi, K. B., Bodin. S., de Kaenel, E., Matera, V., and Adatte, T.: Stratigraphic, sedimentological and palaeoenvironmental constraints on the rise of the Urgonian platform in the western Swiss Jura, Sedimentology, 57, 1088-1125, 2010.

Heldt, M., Bachmann, M., and Lehmann, J.: Microfacies, biostratigraphy, and geochemistry of the hemipelagic BarremianAptian in north-central Tunisia: Influence of the OAE 1a on the southern Tethys margin, Palaeogeogr. Palaeocli., 261, 246-260, 2008.

Herbert, T. D.: Paleomagnetic calibration of Milankovitch cyclicity in Lower Cretaceous sediments, Earth Planet. Sci. Lett., 112, 1528, 1992.

Hoedemaeker, P. J. and Leereveld, H.: Biostratigraphy and sequence stratigraphy of the Berriasian-lowest Aptian (Lower Cretaceous) of the Rio Argos succession, Caravaca, SE Spain, Cret. Res., 16, 195-230, 1995.

Jenkyns, H. C.: Cretaceous anoxic events. From continents to oceans, J. Geol. Soc. London, 137, 171-188, 1980.

Kemper, E. and Zimmerle, W.: Die anoxischen Sedimente der prä-oberaptischen Unterkreide NW-Deutschlands und ihr paläogeographischer Rahmen, Geol. Jb., A 45, 3-41, 1978.

Masse, J.-P. and Fenerci-Masse, M.: Time contrasting palaeobiogeographies among Hauterivian-lower Aptian rudist bivalves from the Mediterranean Tethys, their climatic control and palaeoecological implications, Palaeogeogr. Palaeocli., 269, 5465, 2008

Menegatti, A. P., Weissert, H., Brown, R. S., Tyson, R. V., Farrimond, P., Strasser, A., and Caron, M.: High-resolution $\delta^{13} \mathrm{C}$ stratigraphy through the early Aptian "Livello Selli" of the Alpine Tethys, Paleoceanography, 13, 530-545, 1998.

Mort, M., Adatte, T., Föllmi, K. B., Keller, G., Steinmann, P., Matera, V., Berner, Z., and Stüben, D.: Phosphorus and the roles of productivity and nutrient recycling during oceanic event 2, Geology, 35, 483-486, 2007.

Mutterlose, J. and Ruffell, A.: Milankovitch-scale palaeoclimate changes in pale-dark bedding rhythms from the Early Cretaceous (Hauterivian and Barremian) of eastern England and northern Germany, Palaeogeogr. Palaeocli., 154, 133-160, 1999.

Mutterlose, J., Pauly, S., and Steuber, T.: Temperature controlled deposition of Early Cretaceous (Barremian-early Aptian) black shales in an epicontinental sea, Palaeogeogr. Palaeocli., 273, 330-345, 2009.

Mutterlose, J., Malkoc, M., Schouten, S., Sinninghe Damsté, J. S., and Forster, A.: TEX $_{86}$ and stable $\delta^{18} \mathrm{O}$ paleothermometry of Early Cretaceous sediments: Implications for belemnite ecology and paleotemperature proxy application, Earth Planet. Sci. Lett., 298, 286-298, 2010.

O'Dogherty, L. and Guex, J.: Rates and patttern of evolution among Cretaceous radiolarians: relations with global paleoceanographic events, Micropal., 48 (Suppl. 1), 1-22, 2002.

Renz, P. and Habicht, K.: A correlation of the Tethyan Maiolica Formation of the Breggia section (southern Switzerland) with Early Cretaceous coccolith oozes of Site 534A, DSDP Leg 76 in the western Atlantic, Eclog. Geol. Helv., 78, 383-431, 1985.

Rieber, H.: Eine Ammonitenfauna aus der oberen Maiolica der Breggia-Schlucht (Tessin/Schweiz), Eclog. Geol. Helv., 70, 777787, 1977.

Ruffell, A. H. and Batten, D. J.: The Barremian-Aptian arid phase in western Europe, Palaeogeogr. Palaeocli., 80, 197-212, 1990.

Ruttenberg, K. C.: The global phosphorus cycle, in: Biogeochemistry, edited by: Schlesinger, W. H., Elsevier, Amsterdam, 8, 585-643, 2004.

Schlanger, S. O. and Jenkyns, H. C.: Cretaceous oceanic anoxic events: causes and consequences, Geol. Mijnbouw, 55, 179-184, 1976.

Shipboard Scientific Party: Site 1149, in: Proceedings of the Ocean Drilling Program, Initial Reports 185, edited by: Plank, T., Ludden, J. N., Escutia, C., Abrams, L., Alt, J. C., Armstrong, R. N., Barr, S., Bartolini, A., Cairns, G., Fisk, M. R., Guèrin, G., Haveman, S. A., Hirono, T., Honnorez. J., Kelley, K. A., Larson, R. L., Lozar, F. M., Murray, R. W., Pletsch, T. K., Pockalny, R. A., Rouxel, O., Schmidt, A., Smith, D. C., Spivack, A. J., Staudigel, H., Steiner, M. B., and Valentine, R. B.: College Station, 1-190, doi:10.2973/odp.proc.ir.185.104.2000, 2000.

Sliter, W. V.: Aptian anoxia in the Pacific Basin, Geology, 17, 909912, 1989.

Slomp, C. P., Thomson, J. and de Lange, G. J.: Controls on phosphorus regeneration and burial during formation of eastern Mediterranean sapropels, Mar. Geol., 203, 141-159, 2004.

Sprovieri, M., Coccioni, R., Lirer, F., Pelosi, N., and Lozar, F.: Orbital tuning of a Lower Cretaceous composite record (Maiolica Formation, central Italy), Paleoceanography, 21, 
PA4204, doi:10.1029/2005PA001224, 2006.

Stein, M., Föllmi, K. B., Westermann, S., Godet, A., Adatte, T., Matera, V., and Berner, Z.: Progressive palaeoenvironmental change during the late Barremian - early Aptian as prelude to Oceanic Anoxic Event 1a: Evidence from the Gorgo a Cerbara section (Umbria-Marche basin, central Italy), Palaeogeogr. Palaeocli., 302, 396-406, 2011.

Stein, M., Arnaud-Vanneau, A., Adatte, T., Fleitmann, D., Spangenberg, J., and Föllmi, K. B.: Paleoenvironmental and paleoecological change on the northern Tethyan carbonate platform during the late Barremian-earliest Aptian, Sedimentology, online first, doi:10.1111/j.1365-3091.2011.01286.x, 2012.

Stein, R., Rullkötter, J., Littke, R., Schaefer, R. G., and Welte, D. H.: Organofacies reconstruction and lipid geochemistry of sediments from the Galicia Margin, Northeast Atlantic (ODP-Leg 103), in: Proceedings of the Ocean Drilling Program, Scientific Results, 103, edited by: Boillot, G., Winterer, E. L., Meyer, A. W., Applegate, J., Baltuck, M., Bergen, J. A., Comas, M. C., Dunham, K., Evans, C. A., Girardeau, J., Goldberg, D., Haggerty, J. A., Jansa, L. F., Johnson, J. A., Kasahara, J., Loreau, J.-P., Luna, E., Moullade, M., Ogg, J. O., Sarti, M., Thurow, J., and Williamson, M. A., College Station, 567-585, 1988.

Taylor, S. R. and McLennan, S. M.: The Continental Crust: Its Composition and Evolution, Blackwell, Oxford, 312 pp., 1985.

Taylor, S. R. and McLennan, S. M.: The geochemical evolution of the continental crust, Rev. Geoph., 33, 241-265, 1995.

Tejada, M. L. G., Suzuki, K., Kuroda, J., Coccioni, R., Mahoney, J. J., Ohkouchi, N., Sakamoto, T., and Tatsumi, Y.: Ontong Java plateau eruption as a trigger for the early Aptian oceanic anoxic event, Geology, 37, 855-858, 2009.

Tremolada, F., Erba, E., de Bernardi, B., and Cecca, F.: Calcareous nannofossil fluctuations during the late Hauterivian in the Cismon core (Venetian Alps, northeastern Italy) and in selected sections of the Umbria-Marche Basin (central Italy): paleoceanographic implications of the Faraoni Level, Cret. Res., 30, 505514, 2009.

Tribovillard, N., Algeo, T. J., Lyons, T. W., and Riboulleau, A.: Trace metals as paleoredox and paleoproductivity proxies: an update, Chem. Geol., 232, 12-32, 2006.

Tyson, R. V., Esherwood, P., and Pattison, K. A.: Organic facies variations in the Valanginian-mid-Hauterivian interval of the Agrio Formation (Chos Malal area, Neuquén, Argentina): local significance and global context, in: The Neuquén Basin, Argentina: A Case Study in Sequence Stratigraphy and Basin Dynamics, edited by: Veiga, G. D., Spalletti, L. A., Howell, J. A., and Schwarz, E., Geol. Soc. London, Spec. Publ., 252, 251266, 2005.
Venturati, A.: Planktonic foraminiferal biotic response to the late Hauterivian Faraoni event in the Rio Argos section (southern Spain). International symposium on Cretaceous major geological events and Earth system - workshop on Cretaceous oceanic red beds (IGCP 463 \& 494), 3-5 September 2006, Abstract volume, 46, 2006.

Weissert, H.: Die Paläoozeanographie der südwestlichen Tethys in der Unterkreide, Mitt. Geol. Inst. ETH Zürich Univ. Zürich, 226, 174 p., 1979.

Weissert, H.: The environment of deposition of black shales in the Early Cretaceous: An ongoing controversy, in: The Deep Sea Drilling Project: A Decade of Progress, edited by: Warme, J. E., Douglas, R. G., and Winterer, E. L., SEPM Spec. Publ., 32, 547-560, 1981a.

Weissert, H.: Depositional processes in an ancient pelagic environment: the Lower Cretaceous Maiolica of the Southern Alps, Eclog. Geol. Helv., 74, 339-352, 1981 b.

Weissert, $\mathrm{H}$. and Erba, E.: Volcanism, $\mathrm{CO}_{2}$ and palaeoclimate: a Late Jurassic-Early Cretaceous carbon and oxygen isotope record, J. Geol. Soc. London, 161, 695-702, 2004.

Weissert, H., McKenzie, J. A., and Hochuli, P.: Cyclic anoxic event in the Early Cretaceous Tethys ocean, Geology, 7, 147$151,1979$.

Weissert, H., McKenzie, J. A., and Channell, J. E. T.: Natural variations in the carbon cycle during the Early Cretaceous, in: The Carbon Cycle and Atmospheric $\mathrm{CO}_{2}$ : Natural Variations Archean to Present, edited by: Sundquist, E. T. and Broecker, W. S., Geophys. Monogr. Ser., 32, 531-545, 1985.

Westermann, S.: Trace-element and phosphorus contents in sediments associated with Cretaceous anoxic events, Unpubl. Ph.D. thesis, Univ. Lausanne, 223 pp., 2010.

Westermann, S., Föllmi, K. B., Adatte, T., Matera, V., Schnyder, J., Fleitmann, D., Fiet, N., Ploch, I., and Duchamp-Alphonse, S.: The Valanginian $\delta^{13} \mathrm{C}$ excursion may not be an expression of a global oceanic anoxic event, Earth Planet. Sci. Lett., 290, 118-131, 2010.

Wissler, L., Weissert, H., Masse, J.-P., and Bulot, L. G.: Chemostratigraphic correlation of Barremian and lower Aptian ammonite zones and magnetic reversals, Geol. Rundschau, 91, 272-279, 2002. 